\title{
Capital, Profession and Medical Technology: The Electro-Therapeutic Institutes and the Royal College of Physicians, 1888-1922
}

\author{
TAKAHIRO UEYAMA*
}

That it is undesirable that any Fellow or Member of the College should be officially connected with any Company having for its object the treatment of disease for profit. (Resolution of the Royal College of Physicians of London, 25 Oct. 1888.)

That subject to the general provisions of Bye-law 190 the College desires so to interpret its Bye-law, Regulations, and Resolutions, as no longer to prohibit the official connection of Fellows and Members with medical institutes, though financed by a company, provided there be no other financial relation than the acceptance of a fixed salary or of fees for medical attendance on a fixed scale, irrespective of the total amount of the profits of the Company. (Resolution of the Royal College of Physicians of London, 1922, replacing the Resolution of 1888.)

No Fellow or Member of the College shall be engaged in trade, or dispense medicines, or make any engagement with a Pharmacist [altered from Chemist] or any other person for the supply of medicines, or practise Medicine or Surgery in partnership, by deed or otherwise, or be a party to the transfer of patients or of the goodwill of a practice to or from himself for any pecuniary consideration. (Bye-law 178 of the Royal College of Physicians of London, 1922, alterations in italics.) $)^{1}$

This paper examines the implications of an historical drama at the Censors' Board of the Royal College of Physicians of London (henceforth RCP) in the late 1880s and 1890s. In 1888 the Institute of Medical Electricity, Limited (henceforth IME), which British electrical engineers had founded to explore new electrical business in medicine, began to question the traditional professional ideology of the RCP. Four years later a more commercial enterprise, the Medical Battery Company (henceforth the $\mathrm{MBC}$, later the Zander Institute) initiated a notorious electric belts business and created irksome disciplinary problems for the Censors' Board of the RCP. Supporting the IME were

*Takahiro Ueyama, MA, History Department, Stanford University, Stanford CA, 94305, USA.

My research for this paper was made possible by a fellowship financed by the Toyota Foundation to which I wish to express my gratitude. I would like to thank Derede Arthur, Bettina Bryan, W F Bynum, Christopher Lawrence, Tim Lenoir, Roy Porter, Peter Stansky and Akihito Suzuki for their comments, and three anonymous referees for their helpful criticism on the earlier draft.
${ }^{1}$ The Charter, Bye-laws, and Regulations of the Royal College of Physicians of London and the Acts of Parliament especially relating thereto, London, Harridan and Sons, 1908, pp. 94-5. 'Second report from the Censors' Board on the proposed alteration of a Resolution of the College and of Bye-law CLXXVIII', held by The Royal College of Physicians of London (henceforth RCP), MSS., 835/51. For the Resolution and Bye-law, see the Annals of Royal College of Physicians of London (henceforth Annals), 19 Oct. 1922, vol. 51, f. 159-62. 
medical electricians and the Institution of Electrical Engineers; while the $\mathrm{MBC}$ and its founder, C B Harness, were supported by Dr Herbert Tibbits, a licentiate of the RCP who wrote a laudatory certificate for the MBC's electric belt. Opposing both these groups were traditionalist physicians, and mainstream medical electricians within the IME who, seeking to advance the managerial possibilities of their Institute as well as electricity's practical applications to medicine, attempted to demolish the MBC and Tibbits in court battles. In investigating this struggle, I will show that the interaction between capital, technology, and medicine created in the late nineteenth century a new environment for the medical profession.

Facing the challenges of these upstart Institutes, the RCP was determined to thwart the commercial ventures of such corporate-style medicine. However, as I will show, the conflict between these three groups reveals a new medico-social context in which, just before the turn of the century, the medical profession was experiencing pressure to remodel its ideology in the face of the growing commercialization of medical practice and increased public demand for specialized and technological treatment. I will investigate how the RCP's enactment and amendment of its regulations in 1888 and 1922 was influenced by the two professional ideals of, on the one hand, the physician as gentleman, and, on the other, that of public service, with the latter gradually gaining on the former in the early twentieth century. ${ }^{2}$

\section{Historiographical Context: Medical Commerce and Professional Ideals}

The re-evaluation of medicine's relation to commerce and the marketplace, initiated largely by Roy Porter, has created an understanding of eighteenth-century medicine as clientdominated and market-oriented. ${ }^{3}$ In the free-for-all, regular practitioners had to compete with quack itinerants, nostrum-vendors, and empirics like James Graham, a sex-therapist who employed "magneto-electricity" for nervous ailments and sold "electrical medicaments". On the other hand, "early modern practitioners were involved in the drink trades at various levels". As Margaret Pelling emphasizes, it is difficult to split eighteenth-century medical practitioners into professionals and traders solely on the basis of their performance. ${ }^{4}$

By contrast, in the Victorian era the rise of professionalism via bureaucratic or state control gradually replaced market mechanisms, ${ }^{5}$ and the professionalization of medicine served to strengthen control and to rescue the profession from the undignified bogland of the medical market. ${ }^{6}$ State regulations such as the Apothecaries Act of 1815 and the

\footnotetext{
${ }^{2}$ Harold Perkin, The rise of professional society, London and New York, Routledge, 1989. For the increased importance of the public service ideal for the medical profession, see Andrew Morrice, "The medical pundits": doctors and indirect advertising in the lay press 1922-1927', Med. Hist., 1994, 38: 255-80.

3 Roy Porter, Health for sale: quackery in England 1660-1850, Manchester and New York, Manchester University Press, 1989; Nicholas D Jewson, 'Medical knowledge and the patronage system in eighteenth-century England', Sociology, 1974, 8: 369-85; Michael Neve, 'Orthodoxy and fringe: medicine in late Georgian Bristol', in W F
}

Bynum and R Porter (eds), Medical fringe \& medical orthodoxy 1750-1850, London, Croom Helm, 1987.

4 Margaret Pelling, 'Medical practice in early modern England: trade or profession?', in Wilfrid Prest (ed), The professions in early modern England, London, Croom Helm, 1987, p.104.

5 Magali Larson, The rise of professionalism: $a$ sociological analysis, Berkeley and Los Angeles, University of California Press, 1977.

6 For the occupational diversity in the eighteenth century, see Margaret Pelling, 'Occupational diversity: barbersurgeons and the trades of Norwich, 1550-1640', Bull. Hist. Med., 1982, 56: 484-511. 


\section{Takahiro Ueyama}

Medical Act of 1858, traditional historiography has argued, were introduced to reinforce the boundaries of the medical profession. ${ }^{7}$ On the doctor's side, an ethical or moral code of behaviour powerfully reinforced professional solidarity. According to Jeanne Peterson, London consultants used their patronage and posts in voluntary hospitals to acquire wealthy patients for their own lucrative private practices, while at the same time protecting the esprit de corps of the medical profession by insisting on gentlemanly professional standards for the large mass of practitioners. This created an ethos in which advertising or pecuniary ventures by a doctor were seen as unprofessional and unseemly. ${ }^{8}$

However, more recent historiography has viewed the effectiveness of state regulation as limited. ${ }^{9}$ The Medical Act of 1858 , for example, was far less restrictive than it appeared on the surface, allowing doctors freedom to espouse any doctrines (quackish or not) that they wished. ${ }^{10}$ Even the professionalization scenario articulated by Peterson ironically brings into relief the intra-professional struggles in which non-élite doctors found a way to break the monopoly of the élite by seeking other methods of financial gain. ${ }^{11}$ At the same time, many medical men, including such practitioners as Robert Abercrombie and Harry Lobb, used self-promotion to become medical entrepreneurs. ${ }^{12}$ Recent studies of the medical market show that harsh competition among a growing number of rank and file practitioners in the nineteenth century created "a significant downward pressure on medical incomes", which compelled them to pursue a more commercial approach, some even going so far as to endorse advertisements and join laymen's medical businesses. ${ }^{13}$

Such collaboration between commercial interests and medical professionals could not long go unchallenged. During the last quarter of the nineteenth century, extraordinary meetings of the Censors' Board, the RCP's disciplinary body, were frequently held to summon those Fellows, Members, and Licentiates whose names had appeared in public advertisements. ${ }^{14}$ Various patent foods and accessories such as Van Houten Cocoa, Coleman's Liebig's Extract of Meat and Malt Wine, and The Ladies' New Sanitary Towel were advertised as having doctors' recommendations and thus medical virtues; all, as a result, incurred RCP censorship. But most controversial were the testimonials or

${ }^{7}$ William Reader, Professional men: the rise of the professional classes in nineteenth-century England, London, Weidenfeld \& Nicolson, 1966.

${ }_{8} \mathrm{M}$ Jeanne Peterson, The medical profession in mid-Victorian London, Berkeley and London, University of California Press, 1978.

9 The Apothecaries Act failed to guard the status of general practitioners. See I Loudon, Medical care and the general practitioner, 1750-1850, Oxford, Clarendon Press, 1987, pp. 297-301.

10 David L Cowen, 'Liberty, laissez-faire, and licensure in nineteenth-century Britain', Bull. Hist. Med., 1969, 43: 30-40. See also vol. 3, by A M Cooke, of $A$ history of the Royal College of Physicians of London, Oxford, Clarendon Press, 1972, p. 908.

${ }^{11}$ Ivan Waddington, 'General practitioners and consultants in early nineteenth-century England: the sociology of an intra-professional conflict', in J Woodward and D Richards (eds), Health care and popular medicine in the social history of medicine,
New York, Holmes \& Meier, 1977; Ivan

Waddington, The medical profession in the industrial revolution, Dublin, Gill and Macmillan, 1984.

12 Peterson, op. cit., note 8 above, ch. 6.

13 I Loudon, op. cit., note 9 above; Anne Digby, Making a medical living: doctors and patients in the English market for medicine, 1720-1911, Cambridge University Press, 1994.

14 See Cooke, op. cit., note 10 above, ch. 40 , p. 902: "In the last quarter of the nineteenth century the College, and in particular the Censors' Board, devoted much time and trouble to disciplinary matters. ... At almost every meeting of the Censors' Board there were several disciplinary items on the agenda, some times as many as nine at a time. Members were sometimes guilty of being associated with trade or of advertising". The advertising files containing a number of the controversial cases of advertisements at the Censors' Board are held in the RCP, MSS., 2412/1-176. 
certificates that doctors gave to such medical goods. ${ }^{15}$ These doctors were censured because they voluntarily involved themselves with commercial activities. In all of these cases, the RCP's rationale was simple: it was "unprofessional" conduct to be officially connected with trade or market activities for the purpose of making profits.

Specialization was another element linked to this market pressure and it troubled the RCP. Although specialists in Britain throughout the nineteenth century were likely to be regarded as quacks, younger aspiring specialists founded their own specialist hospitals with the support of philanthropic laymen; in so doing they attempted to break through the barrier created by the inner circle who monopolized the positions at general hospitals. ${ }^{16}$ For example, the National Hospital for the Paralysed and Epileptic was founded in 1859 to provide electro-therapy for nervous ailments. In 1866 Julius Althaus, an eminent writer about medical electricity, founded a Hospital for Epilepsy and Paralysis, later the Maida Vale Hospital. ${ }^{17}$ Such specialist hospitals multiplied so rapidly and flourished so widely that they could no longer be ignored by the consultants of the general hospitals. ${ }^{18}$

Explaining doctors' market activities and the proliferation of specialist hospitals only from the points of view of medical suppliers, however, neglects another important element: demand. Why did they flourish? Who sustained them? Irrespective of the consultants' concerns for professional ideology and cohesion, consumers of medicine began to demand different medical practices. At least from the late nineteenth century, when the weight of medical authority was passing from an omnicompetent physician performing single-handedly diagnoses and treatments, to more specialized care and institutional treatments, the public's concerns manifested themselves at various levels.

The high demand for specialist hospitals, it has been argued, "underlay the overall success of the specialist hospital movement", and hospitals in turn easily adapted their outpatient facilities to attract and accommodate more patients. ${ }^{19}$ The pay hospital movement, directed by Henry Burdett, was sustained by the middle classes who "could afford to make some payment" for a more refined care than that in voluntary charitable hospitals. $^{20}$ Other private medical institutions also began to be widely established.

\footnotetext{
15 The following are some of the cases: Coleman \& Co., Ltd., 'Unsolicited testimonials from medical men, Coleman's Liebig's Extract of Meat and Malt Wine'; Sir William Broadbent censored in relation to 'Grundy's Heating and Ventilating Apparatus', MSS., 2412/19a; John Attefield, 'Correspondence re circular letter by John Attefield soliciting expert scientific evidence in defence of Van Houten's coca in an action of law', 1893. MSS., 2412/280-284; 'Baby Magazine: correspondence re names of Fellows of RCP appearing in advertisement for Baby', MSS., 2412/33-44; 'William Chapman Grigg: correspondence re testimonial by Dr Grigg for Liq. Euonymin et Pepsin Co. published by Oppenheimer Bros. \& Co. 1884-85', MSS., 2412/100-105; 'Archibald Keightley: correspondence relating to Archibald Keightley's name being used in advertisements for Miss Ellen Jewson's Home for the Dietetic and other treatment of Chronic Disease, 1894', MSS., 2412/150-153; 'Charles Henry Leet: testimonials in favour of Charles Henry Leet, used in
}

advertisements. With advertisement for Dr. Leet's Pills, 1886-94', MSS., 2412/154-56.

16 Rosemary Stevens, Medical practice in modern England: the impact of specialization and state medicine, New Haven and London, Yale University Press, 1966.

${ }^{17}$ Peterson, op. cit., note 8 above pp. 264-6; Richard Kershaw, Special hospitals, London, Pulman, 1909.

18 Lindsay Granshaw, 'Fame and fortune by means of bricks and mortar: the medical profession and specialist hospitals in Britain, 1800-1948', in Lindsay Granshaw and Roy Porter (eds), The hospital in history, London, Routledge, 1989; Stevens, op. cit., note 16 above, pp.27-8.

19 Granshaw, ibid., p.206.

20 Brian Abel-Smith, The hospitals, 1800-1948: a study in social administration in England and Wales, London, Heinemann, 1964, ch.9. 


\section{Takahiro Ueyama}

Nursing homes, which were mostly run by non-medical proprietors and which by 1900 in London alone numbered more than fifty, provided an alternative to pay wards in the hospitals. ${ }^{21}$ As Michael Worboys has shown, private sanatoria for consumption and cancer founded by business-minded practitioners largely outnumbered public ones until 1907.22 In essence, the fashionable spas of the eighteenth century and the faith in water cures were refurbished through venture capital. Lay-owned institutions such as the one at Malvern run by John Gully attracted thousands of patients including Charles Darwin. ${ }^{23}$ In the 1870s a Matlock businessman, John Smedley, made a considerable fortune from the 172bed capacity of the Hydropathic Institution he had built. ${ }^{24}$ Similarly, herbal medicine, a self-help practice, grew more commercial in the 1870 s as profitable medical institutions were established. One of these was the Medical Botanical Institute opened in Southampton Street, Camberwell, by a medical herbalist, D Stokes. ${ }^{25}$

Para-medical activities, which were beginning to acquire a recognized place in the medical division of labour in the late nineteenth century, were linked to this new domain of institutional treatment. Massage, newly legitimated as an auxiliary treatment in hospitals, was developed into a more professional physiotherapy. ${ }^{26}$ Massage departments began to be established both in general and specialist hospitals. Many of the business institutions, such as nursing homes, advertised treatment by massage and Swedish medical gymnastics under the aegis of resident physicians. $^{27}$ The recognized usefulness of X-rays for diagnosis nurtured the teamwork between physicians or surgeons and radiologists or radiographers in hospitals. ${ }^{28}$ Collaboration between physicians and skilled specialists, though maintaining a somewhat hierarchical structure, was supposed to produce better treatment for patients. ${ }^{29}$ As a result of this partnership, management and administration grew in importance in order to ensure that the consumer's needs were met. ${ }^{30}$ In this environment, capital ventures would be parasitic.

21 Matthews' manual of nursing homes, \& hydros of the British Isles and guide to spas and health resorts, London, Alex. Matthews, 1915.

22 Michael Worboys, 'The sanatorium treatment for consumption in Britain, 1890-1914, in John Pickstone (ed.), Medical innovations in historical perspective, New York, St Martin's Press, 1992.

23 Janet Browne, 'Spas and sensibilities: Darwin at Malvern', in Roy Porter (ed.), The medical history of waters and spas, Medial History Supplement No.10, London, Wellcome Institute for the History of Medicine, 1990.

24 Kelvin Rees, 'Water as a commodity: hydropathy in Matlock', in Roger Cooter (ed.), Studies in the history of alternative medicine, Basingstoke, Macmillan, 1988.

25 The Medical Botanical Institute which supplied "Herb Healing", was censored by the RCP, MSS., $2412 / 95$.

26 In 1894 the trained nurses had founded the Society of Trained Massage which developed into the modern Chartered Society of Physiotherapy in 1944. See Jean Barclay, In good hands: the history of the Chartered Society of Physiotherapy 1894-1994, London, Butterworth Heinemann, 1994. Massage, an old popular healing, was revived in the 1880 s. J Althaus referred to it as the "Cinderella of therapeutics", see, "The risk of "massage", $\mathrm{Br}$. med. J., 1883, ii: $1223-4$.

27 Matthews' manual, op. cit., note 21 above.

28 The development of paramedical professions has been examined by Gerald Larkin, 'The emergence of para-medical professions', in W F Bynum and Roy Porter (eds), Companion encyclopedia of the history of medicine, London and New York, Routledge, 1993, vol. 2, pp.1329-49; idem, Occupational monopoly and modern medicine, London, Tavistock, 1983. For medicine's internal structure and division of labour, see Harry M Marks, 'Notes from the underground: the social organization of therapeutic research', and Rosemary Stevens, 'The curious career of internal medicine: functional ambivalence, social success', both in Russell C Maulitz and Diana E Long (eds), Grand rounds: one hundred years of internal medicine, Philadelphia, University of Pennsylvania Press, 1988.

29 For this line of argument with emphasis on hierarchical structure of medicine, see Roger Cooter, Surgery and society in peace and war: orthopaedics and the organization of modern medicine, 1880-1948, Basingstoke, Macmillan, 1994.

30 For a detailed elaboration of this change in twentieth-century medicine, see Steve Sturdy, 'The political economy of scientific medicine: science, 


\section{The Electro-Therapeutic Institutes and the RCP}

Could doctors be completely indifferent to this new phase of medicine? Did the public's concerns have no influence on the professionalization of British medicine at all? Even though recent studies of American medicine have stressed the role of the market forces by which occupational competition brought new technologies and speciality services into medicine to attract patients, ${ }^{31}$ many historians have been reluctant to see a similar pattern in British medicine. That which was technological, mechanical, or practical is said to have been incompatible with the deep-seated ideological narratives legitimating the rhetorical tradition of the gentleman. ${ }^{32}$ However, this oft-articulated "Britishness" may underestimate the commercialization and specialization of medicine and the impact of this on the professionalism of the élite.

In fact, acknowledgment of medicine's responsibility to serve the public need came gradually but steadily, although substantial resistance to any dispersal of centralized professional control lingered on. In 1905 Squire Sprigge, of the Lancet, responded to the public demand for medicine's rehabilitation in his treatise Medicine and the public. Both the public's increasing belief in specialism and its unwillingness to accept high consultant fees, he lamented, promoted "the abuse of specialist hospital[s]". Moreover, he complained, through market forces generated by medical aid associations or corporatestyled institutions, "the public has attempted . . . to obtain mastery over medical service". 33 Enumerating these "difficulties which medical men undergo in their professional duties", Sprigge wished to evoke "a more widespread sympathy" and to seek "proper co-operation between the medical men and the public". ${ }^{34}$ Some of Sprigge's views eventually carried the day: the medical élite gradually became more attuned to what the public wanted and to public service. Gentlemanly "medical etiquette", though still emphasized, was extended beyond partisan prerogative to embrace an ethos of "serving the public". 35

In the late nineteenth century, however, such ideas were still regarded as subversive. Nevertheless, the two electro-therapeutic institutes here investigated did combine corporatist medical services with new, specialized technology in response to changing public demand. In so doing, they allowed entrepreneurs to take over a hitherto unoccupied niche of the medical world. Unlike old narrow-minded merchants, the entrepreneurs of medical electricity in the $1880 \mathrm{~s}$ and $1890 \mathrm{~s}$ transformed or appeared to transform

education and the transformation of medical practice in Sheffield, 1890-1922', Med. Hist., 1992, 36: 125-59.

31 Joel Howell, Technology in the hospital: transforming patient care in the early twentieth century, Baltimore and London, Johns Hopkins University Press, 1995. Glenn Gritzer and Arnold Arluke, The making of rehabilitation: a political economy of medical specialization, 1890-1980, Berkeley, University of California Press, 1985; Paul Starr, The social transformation of American medicine, New York, Basic Books, 1982; Charles Rosenberg, The care of strangers: the rise of America's hospital system, New York, Basic Books, 1987; Morris Vogel, 'Managing medicine: creating a profession of hospital administration in the United States', in Granshaw and Porter (eds), op. cit., note 18 above.
32 Christopher Lawrence, 'Incommunicable knowledge: science, technology, and the clinical art in Britain, 1850-1914', J. contemp. Hist., 1985, 20: 503-20; idem, 'Moderns and ancients: the "new cardiology" in Britain 1880-1930', in W F Bynum, C Lawrence, V Nutton (eds), The emergence of modern cardiology, Medical History Supplement No. 5, London, Wellcome Institute for the History of Medicine, 1985; also in his unpublished discussion paper, 'Still incommunicable: clinical knowledge between the wars'.

33 S Squire Sprigge, Medicine and the public, London, Heinemann, 1905, p. 51.

34 Ibid., p. 45.

35 Ibid., p. 246. 


\section{Takahiro Ueyama}

themselves into more modern professional "Institutes", financed and organized by private companies. The organizers professed to share profits from selling medical services and appliances with the professional medical men affiliated with these companies. A form of collaboration between capital and profession was emerging, which was seen as a serious threat to the integrity of the medical profession, as was the different code of behaviour initiated by these Institutes. Faced with the strategies adopted by medical electricians, the gentlemanly ethos of the physicians of the RCP turned out to be far from unshakable. Indeed, the questions that most demand answers are: what was the real threat, and what the medico-social context veiled behind the fault-finding chorus of "unprofessional and ungentlemanly standards" in the 1880 s and 1890 s? By the late nineteenth century medical electricity was no fly-by-night, accidental business. It was a promising springboard for the large-scale capitalization of medicine.

\section{The Institute of Medical Electricity and the RCP}

In the 1830 s and 1840 s, as Iwan Rhys Morus has recently shown, electricity was added to time-honoured, popular therapeutic practices and became "viable medicine". This acceptance resulted largely from the "rhetorical and practical strategies" adopted by medical electricians such as Golding Bird and Thomas Addison at Guy's Hospital. ${ }^{36}$ Thirty years later, the British Medical Journal admitted that "the substantial value of electricity as a remedy has now become an acknowledged fact; and the doubts which were formerly expressed as to its real usefulness have been dispelled by the advance of science". ${ }^{37}$ In fact, it seemed as if medical electricity was advancing further and further into legitimate medical practice with each passing year: the 1880 s and 1890 s, in particular, witnessed its move from hospital experimentation into more mature and more practical therapeutics relying heavily on the technical application of electric machines and facilities. Indeed its potential in practical therapeutics seemed sufficiently promising to lure self-interested professional electrical engineers into the field of medicine.

In 1871, British practical electricians had founded the Society of Telegraph Engineers and Electricians (henceforth STEE). It emerged from the interest in electricity promoted by the London Electrical Society, an organization with which early medical electricians like Golding Bird had remained in close contact, and which was the parent society of the modern Institution of Electrical Engineers (henceforth IEE) ${ }^{38}$ By the early 1880 s, many members of the STEE had become associated with new commercial medical institutions. In particular, the Institute of Medical Electricity, established in 1888 by Henry Newman Lawrence, a member of the IEE, provided an important demonstration of how private enterprise could encroach on professional territory.

\footnotetext{
36 Iwan Rhys Morus, 'Marketing the machine: the construction of electrotherapeutics as viable medicine in early Victorian England', Med. Hist., 1992, 36: 34-52.

37 'Report on modern medical electric and galvanic instruments, and recent improvements in their application: with special regard to the
}

requirements of the medical practitioner', Br. med. J., 1873, i: $44-6,144-6,344-5,740-2$, and ibid., ii: 493-7, 614-15, 704-5.

38 Iwan Rhys Morus, 'Currents from the underworld: electricity and the technology of display in early Victorian England', Isis, 1993, 84: 50-69. 


\section{The Electro-Therapeutic Institutes and the RCP}

The IME was formed in 1887 as a joint stock company capitalized at $£ 20,000$ in $£ 1$ shares with subscribers recruited from both the electrical and medical professions. ${ }^{39}$ With William Lant Carpenter, a Member of the STEE, as the director and Henry Lawrence as the managing director, the Institute commenced its medical services at 24A, Regent Street in September $1888 .{ }^{40}$ To emphasize its genuine medical purpose, the Institute obtained support from "several of the best medical men" including a past president of the Royal College of Surgeons (1882), Sir T Spencer Wells, and the current vice-president of the Royal College of Physicians, C Handfield Jones. ${ }^{41}$

However, this medical Institute was not organized and led by medical men but by electrical engineers. Those associated with the Institute, "trustworthy members of the Society of Telegraph Engineers and Electricians", were leading electrical engineers of the time such as Silvanus Thompson, D E Hughes, J Hopkinson, W S Ayrton, W H Preece, E Graves, C E Spagnoletti, Latimer Clark, and Gisbert Kapp. Most of them were founders of the STEE, past, current or future presidents of the STEE or the IEE, and Fellows of the Royal Society. ${ }^{42}$ On opening his electro-therapeutic business, Henry Lawrence became an Associate Member of the IEE in 1888 and was promoted to Member in 1890 with the support of Silvanus Thompson, under whom he had studied electrical mechanics at Finsbury Technical College. ${ }^{43}$ Through personal connections in the IEE, Lawrence recruited the associates of his Institute from the ranks of eminent engineers. Their enthusiastic commitment to and commercial entry into the domain of medicine heralded the advent of a new social context within which a rival profession began to cast its enterprising eye on electro-medical technology.

Business opportunities in medicine, it seems, aroused much interest among electrical engineers. The Electrician, the journal devoted to the ideas of a wide range of electrical engineers including industrial managers, noted the opening of the IME several times in its columns and published an introductory article on it from which we know the actual electro-therapeutic work undertaken by the Institute. ${ }^{44}$

In addition to the considerable amount of capital invested in the "high-class instruments" and the involvement of highly esteemed professionals, the extensively organized nature of managerial medicine differentiated the Institute from old ventures of commercial medicine. The medical officers employed by the Institute made prescriptions for patients, on the basis of which "skilled attendants" provided electrical treatments. ${ }^{45}$ One such physician was Dr Arthur Harries. Lawrence and Harries were colleagues of long standing: Harries had lectured jointly with Lawrence on 'Electro-therapeutics' and coauthored with him a popular handbook, Practical lessons in electro-therapeutics. ${ }^{46}$

\footnotetext{
39 'Institution of Medical Electricity Limited', The Telegraphic Journal and Electrical Review, 17 Feb. 1888, 22: 168.

40 The Electrician, 13 July 1888, 21:295.

41 The Electrician, 17 Feb. 1888, 20: 370-1.

42 The letter from Lawrence to the President of the RCP includes the names of those on the Board of the IME. See Annals, 1888, 35: 207. Also see the Memorandum attached to the letter in the Annals, "Enclosure A and B", 1888, 35.

${ }^{43}$ See Lawrence's membership form held in the
}

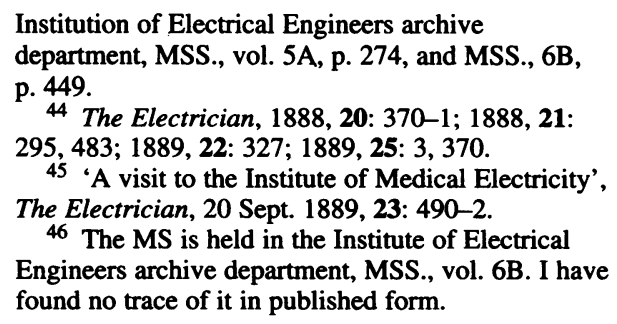




\section{Takahiro Ueyama}

Lawrence's Institute had all the trappings of medical professionalism. ${ }^{47}$ Patients were treated in different types of electrical rooms. On the walls of each room were "switch boards arranged with suitable connections for supplying by rheostat all the forms of current", from $2000 \mathrm{ohms}$ to 12,000 ohms. A variety of innovative machines dictated the purpose of each room. The room for "the electro-gymnastic system", for example, held Lawrence's newly patented gymnastic machines for mechanical exercise (Figure 1). Connected with the switchboard, the apparatus was designed to conduct the current to or from the patient's body during his physical exercise via floor electrodes of fine wire gauze at his feet, by handle electrodes through his hands, and by bandage electrodes through his arms or legs. The combination of mechanical exercise and electro-therapeutics became fashionable in commercial medicine.

In the so-called "electrified room", "the air-space between floor and ceiling [was] converted into an electric field by the use of alternating-currents of high potential". Both the floor, covered with sheet lead, and the "ceiling of light brass work" were connected with a powerful induction coil. When standing, sitting or lying in this electrical field, a patient was supposed to obtain a tonic effect by being "electrically influenced without experiencing any shock". Moreover the form of treatment most practised in this room was "electro-manipulation" introduced by Lawrence: he insisted that while a patient was in this "field", the effect on the limbs or body could be enormous if they were massaged by a manipulator electrified by "the high potential alternating currents". The bathroom contained "a large, well insulated oak bath, having connections conveniently arranged round it, with a switch-board". In the experiment room, a newly patented "ozonized cabinet" had been installed to treat "certain chest diseases by strongly (electrically) ozonized air, aided by exercise to deepen respiration". 48

Most noteworthy, however, was the naked commercialism of this Institute. Significantly, the founder announced that profits from the Institute's medical services were exclusively intended for the professionals. Henry Lawrence proposed that: "the shares were offered to Medical and Electrical men only, in order that the control should be and remain in the hands of those two professions, and that the profits should belong to those legitimately interested in the work" 49

Lawrence and the Institute's associated professional engineers naively believed that electrical technology, applied to medicine, would be a good source of income; they did not anticipate opposition on ethical grounds from the medical authorities. There is an interesting contrast between the medical and engineering élites in their professional ethos and morality regarding commercialism. One of the objects listed in the Institute's prospectus was "To provide an institute where, or in connection with which, people of small or limited means may obtain electrical treatment under the direction of qualified medical men, for the cure and relief of diseases, at moderate fees".${ }^{50}$ For the members of the Institute, however, practising electro-therapeutics for the benefit of the public was in

47 See the Pamphlets of the IME held in the Institution of Electrical Engineers, Thompson Pamphlet Collection, Electro-physiology I, SPT 116/5-9 and SPT 116/11.

48 The Electrician, op. cit., note 45 above.

49 Annals, 'The letter from Lawrence to the Registrar of the RCP', 5 May 1888, 35: 207.

\footnotetext{
50 The other two objectives in the Prospectus were: "to encourage the development of the science of medical electricity, and to provide a means by which medical men can obtain the use of reliable electrical apparatus either at the institute or elsewhere".
} 
The Electro-Therapeutic Institutes and the RCP

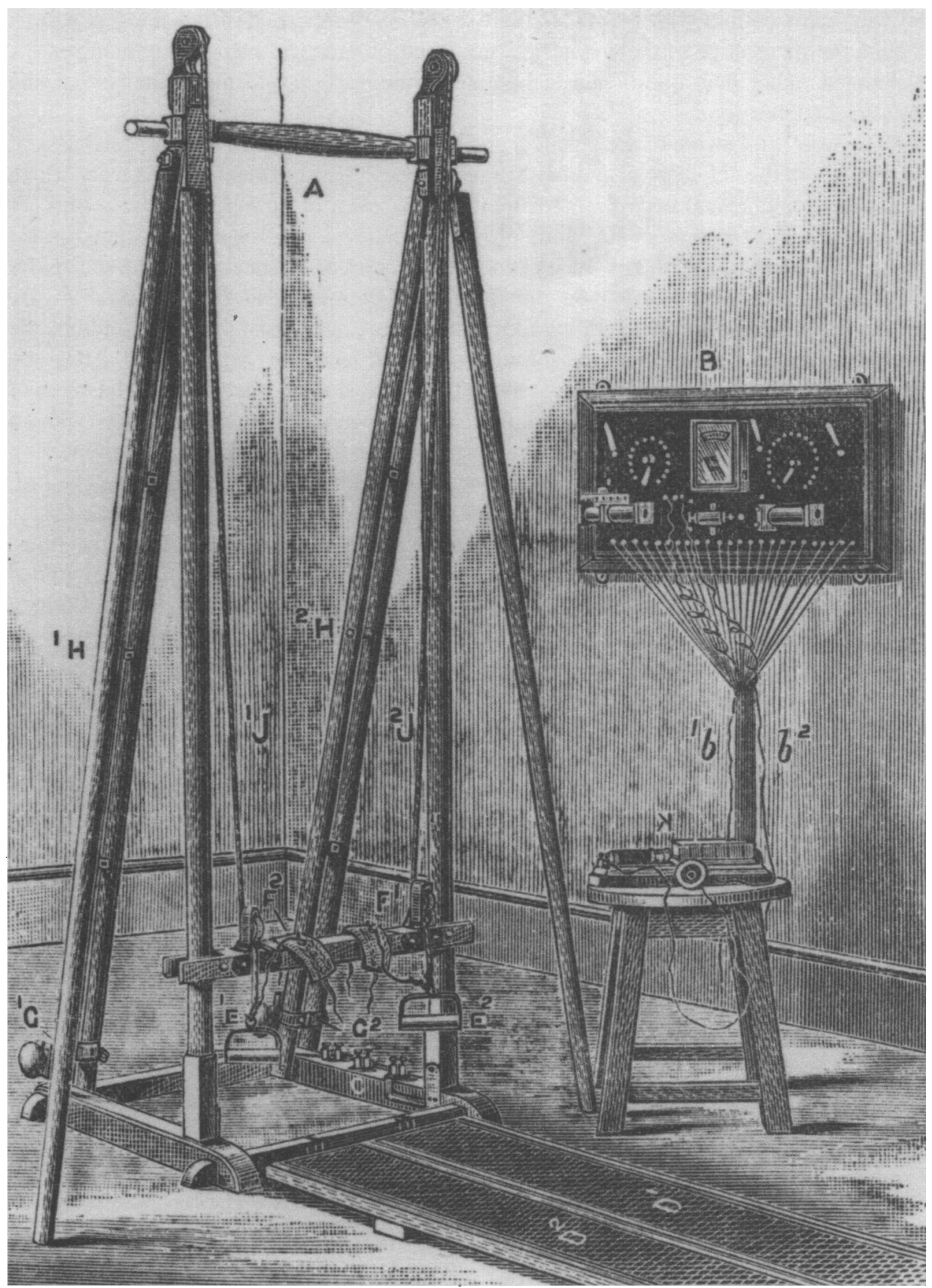

Figure 1: The IME's machine for mechanical exercise as reproduced in The Electrician, 20 September 1889. (Reproduced by permission of the Electrical Review.) 


\section{Takahiro Ueyama}

no way incompatible with monopolizing the pecuniary advantage from these practices. Unlike the medical élite, the engineers, "governed by practical men of common sense", welcomed rather than questioned technological innovations and their commercial and industrial applications.

They were well aware of the practical applicability of science and the purposiveness of technology in the commercial and industrial spheres: 51 "Every scientific discovery which is applied for practical ends becomes more fertile, even of purely scientific results". 52 "One of the most important functions of the engineers . . .", John Perry argued in his inaugural address, was "to convince capitalists ignorant of science that if the successful laboratory experiment is tried on the large scale it must also be successful". ${ }^{53}$ By promoting this business applicability, "our Institution . . . can assist the manufacturers, the designer, the contractor, the consulting engineers, and the capitalist".54 Thus the engineering profession was concerned about the depression of "the trade and business of private enterprise" by the state monopoly. When "persons high in authority, without practical knowledge, but fascinated by an invention" ran the administration of engineering enterprises at a national level, C W Webber warned, "valuable improvements may be lost, or the profitable use of them postponed, for want of wise expenditure". He went on to say: "The history of this subject, followed through the papers read at this Society's meetings, appears to point to the best results having been obtained when decision has been guided by true commercial principles". 55 For engineers, commercialism realized the optimal economic results of "convenience" and "cheapness" through the market mechanism.

Another element distinguishing the entrepreneurial electricians from the medical élite was the ideology of public duty which they upheld. Edwin Layton described the "professional responsibility" of contemporary American engineers as one "guided by a sense of public duty", extended to include a rejection of bureaucratic authority and a wish to reorganize society. ${ }^{56}$ Though less assertive, British engineers shared this ideology of public service. They guarded the benefits of entrepreneurship against "officialism, and hard-and-fast regulations which, formulated with the best intentions, tend sometimes to interfere with the public convenience". 57 "We public servants", one president commented, "rely on public criticism, and our sole object is to serve our master, with a conscientious determination to do our duty to the best of our ability". 58 The engineers believed that commercialism and technological advances should be applied to medical practice; they could not imagine that the provision of cheap services might be seen as a professional problem.

51 Within the Institution, however, there was a political tug-of-war between theorists and practical men. See Bruce J Hunt, "Practice vs. theory": the British electrical debate, 1888-1891', Isis, 1983, 74: 341-55.

52 'Inaugural Address by G Carey Foster', The Journal of the Society of Telegraph Engineers (henceforth JSTE), 1881, 10: 6.

53 'Inaugural Address by John Perry', The Journal of the Institution of Electrical Engineers (henceforth JIEE), 1900, 30: 53.

54 'Inaugural address by Professor S Thompson', JIEE, 1899, 29: 15.
55 'Inaugural address by C W Webber', JSTE, 1882, 11: 7 .

56 Edwin Layton, The revolt of the engineers: social responsibility and the American engineering profession, Baltimore and London, Johns Hopkins University Press, 1986, pp. 5-6, and ch. 3.

57 'Inaugural address by Sir Henry Mance' JIEE, 1897, $26: 11$.

58 'Inaugural address by William Henry Preece', JIEE, 1893, 22: 40. 


\section{The Electro-Therapeutic Institutes and the RCP}

The IME failed, therefore, to anticipate the reaction of the RCP to the association of its members with a profit-making enterprise. Lawrence had offered the positions of consulting physicians to "two of the most eminent and generally respected authorities upon Medical Electricity", W E Steavenson and William H Stone, MRCP and FRCP respectively. Steavenson accordingly asked the President of the RCP to sanction this:

I have been offered the post of physician to a company that has been formed for supplying electrical appliances to the medical profession, and establishing an Institute for the treatment of patients by electricity. As far as I am able to judge, it appears to be a bona fide and respectable company. I am anxious to know if the Royal College of Physicians would view with disfavour the acceptance by a member of the College of such a post as the one now offered to me. . . I could not accept the post if such a step was disapproved of by the Royal College of Physicians. ${ }^{59}$

In their reply, the Censors' Board of the RCP were highly disapproving "as they considered it unprofessional for a member of the College to ally himself with a commercial company for the treatment of disease" ${ }^{60}$ Sixteen days later, on 26 April, Steavenson apprised the Censors' Board of his obedience to the $\mathrm{RCP}^{61}$ and both Steavenson and Stone unwillingly informed the IME that they declined the posts offered to them.

It would be an over-simplification to conclude from this response that the regulatory power of gentlemanly ethics over the medical profession was overwhelmingly strong. The RCP, as a matter of fact, vacillated when faced with the reiterated protests of the managing director of the IME. In his first letter to the RCP on 5 May, Henry Lawrence emphasized the "genuine and bona fide" character of the Institute, enclosing the memorandums signed by both eminent electricians and medical men who were "of opinion that the objects of the proposed Institute of Medical Electricity are worthy of encouragement and that the plan of management is a good one". ${ }^{62}$ Lawrence drew their attention to the authoritative names among the supporters, six FRS, two past Presidents, two Professors of Physics, one of Mathematics, and some current members of the STEE. That most of the medical men who signed were Fellows of the RCP and some of them significantly involved with the management of the Institute was, however, exactly what irritated the College. These were W H Stone, A D Waller, P H Pye-Smith, T Spencer Wells, J Mitchell Bruce, A Julius Pollock, C Handfield Jones and W Guyer Hunter. To add insult to injury, Lawrence also pointed out a double standard, evidenced by the money-acquiring activities of many RCP Members:

We should also submit that Medical Men who are members of your College do hold office under joint-stock companies, as is instanced by the many insurance companies, and also under institutions worked for profit in connection with the treatment of disease as is instanced by some of the Hydropathic and similar establishments; homes and asylums for insane; and some of the Medical Schools attached to the Hospitals. ${ }^{63}$

Lawrence was right. Behind the officially stated principle of professional morality, many medical men were beginning to form or infiltrate business organizations in order to

\footnotetext{
59 Annals, 'The letter from Steavenson to the Censor's [sic] Board' dated 10 April 1888, 35: 175.

60 Annals, 'Censor's [sic] Reply to Steavenson', $1888,35: 176$.
}

\footnotetext{
61 Annals, 'The letter from Steavenson to the Censor's [sic] Board', 1888, 35: 198.

62 Annals, "Enclosure B", 5 May 1888, 35: 208.

63 Annals, 5 May 1888, 35: 207.
} 


\section{Takahiro Ueyama}

make a profit. In particular, a number of physicians consulted and performed medical examinations for life insurance companies. For example, Sir Douglas Maclagan, David Ferrier and Norman Moore were employed by the Edinburgh Life Assurance Company; John Russell Reynolds and W R Gowers by the Guardian Fire and Life Assurance Company; Sir J Risdon Bennett and P H Pye-Smith by the General Assurance Company, and so on. ${ }^{64}$ Far from the IME's being an exception, it was part of an ongoing, albeit somewhat clandestine, process by which the medical profession accommodated itself to the cash nexus in the late nineteenth century.

To Lawrence's protest, the College responded in a generous fashion, promising that "it would receive a careful consideration". ${ }^{65}$ Lawrence wasted no time in asking the RCP to receive a deputation to discuss and explain "the present position and prospects of the Institute with special reference to its medical offices". 66 On 24 July a few members deputed from the Institute were afforded the chance to urge "the strictly scientific character and necessity for some such institution as that proposed and hoped that the College would permit its Fellows and Members to be appointed with it". 67

Though the deputation seemed to have persuaded the Censors' Board of "the good faith and intention of the prompter of the Institute of Electricity", 68 the RCP held to the view that Bye-law 178 prohibited Fellows and Members from being "engaged in trade". As a last resort, Lawrence petitioned the RCP "to appoint a representative of that body to visit this Institute, inquire into its methods of working, and to make a report thereon to the authorities of your College at his discretion". ${ }^{9}$ The Registrar simply declined this proposal.

The extent to which the RCP was embarrassed and threatened by the newborn corporate-style electro-therapeutic institute is shown by the fact that on 25 October 1888 the College passed a new Resolution which prohibited Members and Fellows from being connected with any "Company" having for its object the treatment of disease for profit. ${ }^{70}$ This was the first and only use of the word "Company" in the Bye-laws and Regulations of the RCP. The IME's championing of the public's welfare seems to have put the RCP on the defensive. Its initial intention, apparently, was to prevent commercial marketing from breaking up the solidarity of "professional" medical ranks. What Paul Starr has argued for early-twentieth-century American medicine is just as applicable to the British medical profession thirty years earlier: "the competitive market represented a threat . . . to [physicians'] status and autonomy because it drew no sharp boundary between the educated and uneducated [and] blurred the lines between commerce and professionalism". ${ }^{71}$

Confronted with the seemingly immovable object of the RCP's Regulation, the electricians in the eighties and nineties attempted to forego the College's approval, but, as a result, the movement towards the commercial practice of medicine that electrotherapeutics had initiated became essentially subterranean. Denied RCP support, the IME

\footnotetext{
64 For the London medical men associated with insurance companies, see the advertisements in the Medical directory, for example "An index to life assurance offices" 1888 , pp. 1552-6.

65 Annals, 5 May 1888, 35: 210.

66 Annals, 6 July 1888, 35: 217.

67 Annals, 24 July 1888, 35: 218-19.
}

68 Annals, 'Reply to Deputation', 24 July 1888, 35: 219.

69 Annals, 'The letter from Lawrence to the Registrar', 7 February 1889, 36: 288.

70 The Charter, Bye-laws, and Regulations, op. cit., note 1 above, p.94.

71 Starr, op. cit., note 31 above, p. 22. 


\section{The Electro-Therapeutic Institutes and the RCP}

was able to continue medical practice under the direction of Lawrence for only two years: "The Institute, after living long enough to prove its utility, but not long enough to pay its expenses under this relentless and powerful persecution, closed its doors". In an article entitled 'Electrifying the Royal College of Physicians' carried in Truth, an anonymous electrician, quite possibly Lawrence, directed his deep resentment towards what he regarded as a bigoted $\mathrm{RCP}$, insisting that medical electricity was nipped in the bud by the very institution that should have fostered it. He compared the RCP to the Church of England:

Between the Royal College of Physicians and the Established Church of England there seems to be a certain fellow-feeling in practice if not in theory. Both aim at respectability, both resent freedom of opinion, both dislike innovation, both are apt to snub original investigations and habitually look askance at new institutions. $^{72}$

On the surface, it appeared that the College's repression was successful. According to Lawrence, electricians and their commercial projects died out, crushed just as, earlier, religious riots had been by that equally benighted institution, the Church: "As with theologians it is not Truth which is of importance, so with the R.C.P. pillars it is not utility or genuineness which is to be consulted. No-in each case it is, as they term it, "the customs and the traditions of this ancient and honourable Corporation'". However, repression did not eliminate these corporate professions. Quietly and through unofficial channels momentum was sustained, ultimately influencing the amendment of the Resolution and Bye-law in 1922.

\section{Electropathic Belts and the Zander Institute}

Despite the RCP's opposition, the uneasy alliance between professional medical men and commercializing electricians continued. The electric belts sold to the public and extensively advertised in the late 1880 s and early 1890 s were generally made up of a flannel bandage long enough to go round the body, with buckles and straps as fasteners. ${ }^{73}$ Between the glazed-calico-covered outside of the bandage and the flannel interior were fixed discs of zinc and copper, usually silver-coated. These discs were connected by wires: zinc to copper, zinc to copper, and so on through the series. Both poles of the belt were set to be connected with any galvanic battery or a portable Leclanché battery. In a most cases, however, the belt was sold with the assumption that no battery would be needed. When the metal discs were placed on the skin, the perspiration of the body was supposed to provide "exciting fluid" to generate electricity by its chemical effect on the zinc discs.

The Medical Battery Company was the most scandalous purveyor of "Electropathic Belts" in late-nineteenth-century Britain (Plates 1 and 2). The company, professedly capitalized at $£ 100,000$, was founded at 52 Oxford Street around 1882 by the aptly named Cornelius Bennett Harness. ${ }^{74}$ His strategy for selling medical goods was highly innovative in comparison with that of the older generation of electrical merchants: out-and-out

\footnotetext{
72 'Electrifying the Royal College of Physicians', Truth, July 1891 , p. 134.

${ }_{73}$ The belt is described in the pamphlet, 'The report on Harness' electropathic belts' by Dr Herbert Tibbits and Dr Arthur Harries, RCP, MSS., 2411/94-95.
} 


\section{Takahiro Ueyama}

marketing campaigns relied upon a combination of advertisements in newspapers, publication of commercial pamphlets, and free use of the authoritative names of distinguished medical men.

Taking advantage of the increased advertising culture of the time, Harness's enormous capital enabled him to do more extensive promotion than the old-style nostrum-vendors whose advertising was limited to a few lines in narrow columns in the newspapers. ${ }^{75}$ Harness bought whole pages in newspapers to display the opinions and testimonials of specialists, patients, and noteworthy persons. The copy included many repetitions of the product's name and sales messages: "HARNESS' ELECTROPATHIC BELTS", "A BOON TO DELICATE WOMEN", "A BLESSING TO WEAK MEN", and so on. 76 Harness marketed his electropathic belts as a panacea for all diseases related to nervous disorders, for example, rheumatism, sleeplessness, and corpulence.

Use of the belt for nervous disorders opened up possibilities for the expansion of its market: Harness touted his belts' potential for treating female sexual diseases as well. To cure female diseases caused by menstrual phenomena, Harness invented a special belt covering a woman's hips. One of the pamphlets published by the MBC described the way in which belts "convey[ing] a series of mild currents to the lumbar and abdominal regions" could have a therapeutic effect on menstrual pains, vaginal discharge, and menopausal disorder. ${ }^{77}$

Harness's commercialism, in short, was extremely audacious. He even listed in his pamphlets a number of physicians and surgeons, headed by the President of the RCP, Sir Andrew Clark, without their consent, blatantly claiming them as the medical patrons "who have sent Patients to this institute, with the utmost satisfaction". ${ }^{78}$ The pamphlets themselves contained excerpts from articles written by authoritative medical electricians, carefully selected to appear as if they guaranteed the therapeutical value of his electric appliances. ${ }^{79}$ Repeated protests from the College to Harness and his company received only the response that "it was for the public benefit that the approval of the Zander System [provided in Harness's Institute] by members of the medical profession should be published". Harness steadfastly refused to remove the names of Fellows. ${ }^{80}$

Harness was attacked from every quarter of the medical world precisely because he was combining commercialism with the semblance of medical professionalism. Electropathic belts smacked of charlatanism, and medical electricians, afraid of reviving the stigma of quackery which had previously been cast upon electro-therapeutics, began to campaign against such new businesses of "Electropathic Appliances" as the MBC. The Lancet and the British Medical Journal collaborated in ostracizing the electric quack and in keeping medical discourse and professional practice inviolate.

\footnotetext{
75 The advertising culture of patent medicine is discussed by Thomas Richards. See ch. 4 of The commodity culture of Victorian England: advertising and spectacle, 1851-1914, London and New York, Verso, 1990.

76 See Daily Telegraph, 9 Jan. 1889; Standard, 14 Nov. 1892.

77 A treatise on the special diseases of women and their electropathic treatment, London, Medical Battery Company Limited, 1891.
}

\author{
78 Swedish mechanical exercise, a means of cure \\ and for the prevention of disease, Medical Battery \\ Company Limited, 1889, p. 3. \\ 79 The eminent doctors whose names Harness \\ misused numbered more than 150 and included \\ Sir Andrew Clark, Sir James Paget, Dr Charles B \\ Radcliffe and Dr Hughes Bennett. \\ 80 Annals, 7 Feb. 1889 , pp. $290-3$. See also \\ Cooke, op. cit., note 10 above, p. 904 .
}




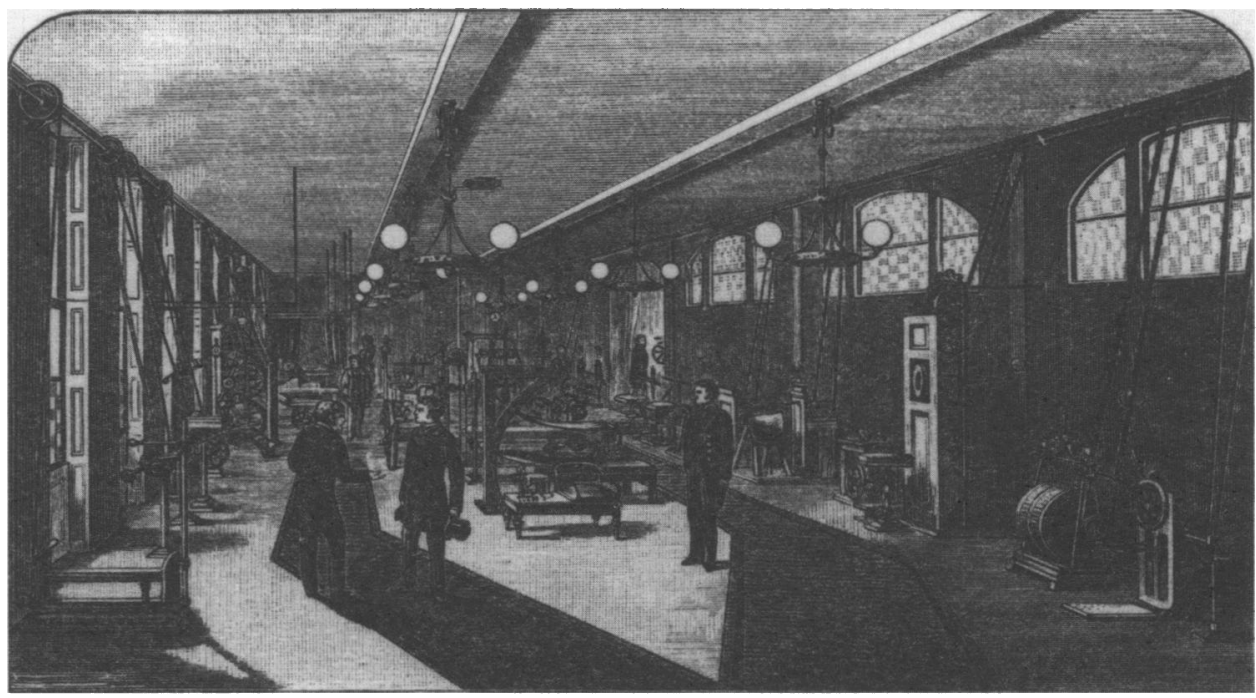

Figure 2: Harness's Zander machines from an illustration in Swedish mechanical exercise, Medical Battery Co. Ltd, 1889. (Reproduced by permission of the British Library.)

The establishment and growth of the MBC was undoubtedly a signal event in the ingenious abuse of medical professionalism by entrepreneurs, representing a latenineteenth-century amalgamation of specialist techniques with commercial endeavour. Typical of this was Harness's strategy of establishing a medical "Institute" both to make his business appear more professional and to turn medical techniques to good account. At the Institute's inception, Harness announced the opening of a "special department for the treatment of certain diseases by the employment of Massage combined with Electrization", which he called the "Electropathic and Zander Institute" (Figure 2). ${ }^{81}$ The Zander system was a newly imported gymnastic method invented by the Swedish physician Dr Jonas Gustaf Wilhelm Zander; it relied upon specially constructed mechanical apparatus to promote the exercise and activity of the muscles. ${ }^{82}$ Harness wasted no time in investing in these costly Swedish machines and in selling institutionalized mechanical exercise through his Zander Institute.

Zander had based his Medico-Mechanical Gymnastics on the so-called "movement cure" developed by his Swedish predecessor, Per Henrik Ling. Ling believed that "the oneness of the human organism, and the harmony between mind and body and between the various parts of the same body" could be realized by prescribed movements of muscles. He thought that to raise the arms in a haphazard fashion produced few corporeal and no mental effects, while on the other hand a "Gymnastic Movement", stretching particular muscles with forces exactly determined so as to provide properly calculated

81 'Electropathic \& Zander Institute, London', RCP, MSS., 2412/131.

82 The Zander system was introduced to the public through several publications, for example, gymnastics: its method, importance, and application, Stockholm, Nordstedt \& Söner, 1893, Gustaf Zander, The apparatus for medico-mechanical gymnastics, Alfred Levertin, $\operatorname{Dr} G$ Zander's medico-mechanical Stockholm, Nordstedt \& Söner, 1894. 
resistance, would inevitably make the body and mind healthier. ${ }^{83}$ Ling classified all physical movements as active or passive: the active exercises were those in which the exerciser encountered resistance through bending, stretching, or twisting his joints, while the passive ones comprised all the operations performed on an inert body, such as rubbing, tickling, tapping, and kneading of muscles.

Influenced by Ling's method early in his professional career, Zander soon recognized its defects: the difficulties not only in accurately adjusting the amount of force to the strength of a patient, but also in the human subject's balancing the movement necessary for the development of muscles with the gradual increase of force. It seemed to Zander that the best way to overcome this difficulty was to replace human agency by machinery. He invented various machines, one of which was awarded a silver medal at the Paris Exhibition of 1878, and another which received a gold medal at the Scientific Exhibition of 1879. Sketches of typical Zander machines appear in Figures 3 and 4. The machine in Figure 3 is designed for active movement to promote the flexion of the forearms. Requiring the arms to bend upwards and stretch downwards as far as possible, it acts primarily on the flexor muscles of the forearms and the muscles of the back. The machine in Figure 4, by contrast, is designed for passive movement. The patient's arms reach through the rubbing-straps, which are covered with a roughened surface and move upwards and downwards: the machine was supposed to massage the arms and produce a very pleasant friction. In the late nineteenth century, the Zander apparatus and its physical methods were introduced in other countries, and Zander Institutes proliferated all over Europe. ${ }^{84}$

Zander Gymnastics achieved a toehold in Victorian society as early as 1882 with the opening of the Zander Institute where many gymnastic machines were installed. ${ }^{85}$ The Institute's lengthy booklet, Mechanical exercise, a means of cure, contains a number of woodcuts depicting Victorian gentlemen and women exercising on a variety of machines. ${ }^{86}$ This Institute lasted only briefly, but Cornelius Harness, the ambitious founder of the MBC, did not let slip this opportunity to take over the institution. By acquiring it, Harness obtained the professional sounding title of Institute, access to many new machines, and an established publication format. Subsequently, he focused his entrepreneurial drive on getting his institution and appliances certified by professional medical men.

At the turn of the century, consumer demand encouraged specialized group medicine or institutional treatment based upon collaboration between doctors and specialist technicians. Viewed in this light, Harness's company was not the product of a mere greedy quack. Irrespective of its founder's real intentions, the MBC broke the latest ground in uniting

83 For details of Ling's system, which was first introduced to Britain by Dr Mathias Roth, see Roth's Gymnastic exercises without apparatus, according to Ling's system, for the due development and strengthening of the human body, London, Myers, 1884.

84 By 1906 Zander Institutes had been founded in more than hundred cities in Europe and America, including Berlin, Bonn, Heidelberg, Amsterdam, Budapest, and Chicago. See, A Levertin, F Heiligenthal, G Schütz, and G Zander, The leading

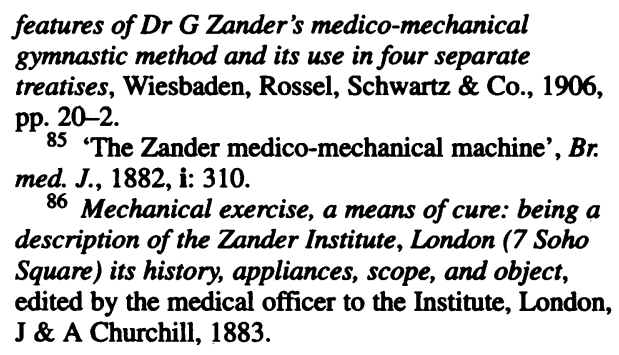
gymnastic method and its use in four separate treatises, Wiesbaden, Rossel, Schwartz \& Co., 1906, pp. 20-2.

85 'The Zander medico-mechanical machine', $\mathrm{Br}$. med. J., 1882, i: 310.

86 Mechanical exercise, a means of cure: being a description of the Zander Institute, London (7 Soho Square) its history, appliances, scope, and object, edited by the medical officer to the Institute, London, J \& A Churchill, 1883. 
The Electro-Therapeutic Institutes and the RCP
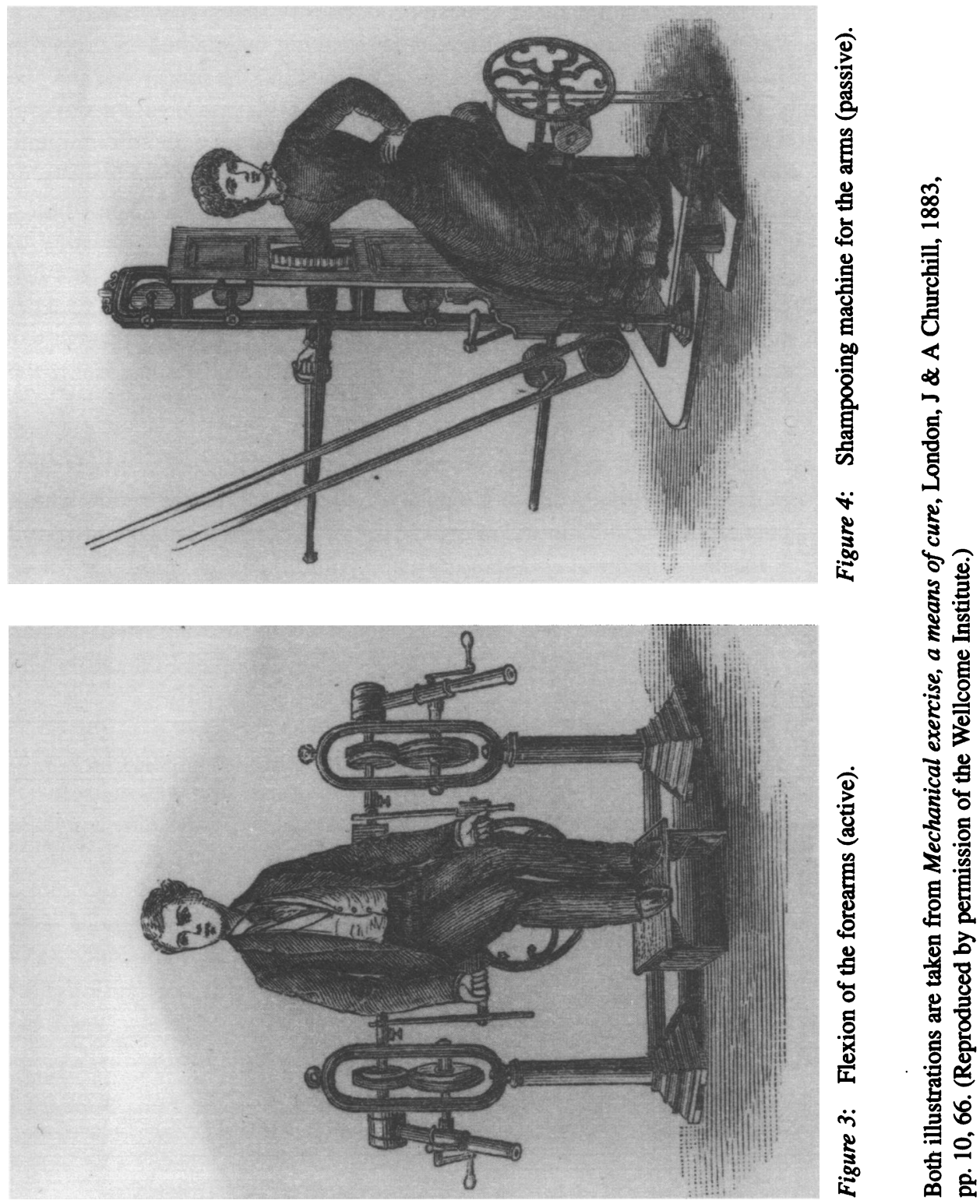


\section{Takahiro Ueyama}

managerial medicine with professional medical practice. But to explain fully how the innovations made in Harness's Institute rendered earlier attempts at medical entrepreneurship outmoded, reference must be made to several factors: the existence of skilled or trained officers, the employment of a team of medical doctors as salaried supervisors, and investment in costly machines and facilities sufficient to achieve economies of scale.

First, Harness was particularly proud that the Zander Institute maintained "a properlyqualified officer who sees each patient, prescribes the machines and the power that shall be used and generally supervises the application". ${ }^{87}$ In the Ladies' Department, "a ski[1]ful and experienced Masseuse has been engaged (who has had the highest scientific training, is the holder of several Hospital Certificates, and also that of the Obstetrical Society of London)". 88 "Qualified Officers, Lady Superintendent, and Certificated Masseuses", giving free consultations, attended every day to give advice on "all matters relating to Health and the application of Electricity as a curative agent, as also Massage, Swedish Mechanical Exercises, Chemical, \&c". ${ }^{89}$ Harness's pride in these ancillary medical practitioners foreshadows the emergence of the division of labour in medical practices.

The second factor, supervision by physicians, was no less important in distinguishing the Zander Institute from its predecessors. In 1887, out of " 129 registered medical men applicants", Harness selected Dr J F Leeson, a Licentiate of the RCP, as the consulting physician, medical superintendent, and expert on "Massage, Medical Electricity and HydroTherapeutics". Leeson described his work in a letter: "I have my counseling room, with a private entrance, patients who consult me are ordered Massage or Electric Belts if considered beneficial, if I think localized electrisation necessary I apply it to them, and those for whom in my judgment, medicine is required I prescribe". 90 Harness attempted to form a "teamwork" approach to medicine among physicians and technical officers. But the recruitment of doctors was soon blocked by the new RCP Resolution of 1888 which prohibited Members and Fellows from being connected with any profit-oriented company. Urged by the Medical Defence Union to denounce Leeson's "association with a notorious quack", 91 the RCP, anxious about the legal power of the College to bind even Licentiates, summoned Leeson to the Censors' Board and successfully forced him to renounce his connection with the MBC. ${ }^{92}$ Though Harness's ambition was thwarted in this instance, the skirmish proved only a prelude to a two-year battle over Dr Herbert Tibbits' employment by the MBC in the early 1890s.

The final factor differentiating the Zander Institute from previous nostrum-vendors, Harness's investment in costly machines, is perhaps best indicated by the comment of its supporter Tibbits that "nowhere have I seen such perfect Static \& other apparatus as is possessed by Mr Harness' company except at the Salpêtrière Paris under Professor Charcot". ${ }^{93}$ In the ample rooms of the Zander Institute, over sixty gymnastic machines were collected to perform their complicated mechanical exercises on patients. ${ }^{94}$

87 Swedish mechanical exercise, op. cit., note 78 above, p. 20.

88 'The pamphlet by the Medical Battery Company', RCP, MSS., 2412/125.

${ }^{89}$ A treatise on the special diseases ..., op. cit., note 77 above, inside front cover and pp. 48-9.

90 Letter from Dr Leeson to Dr Edward Liveing, the Registrar of the RCP, dated 10 Dec. 1887. MSS., 2412/130, Annals, 10 Jan. 1888, 36: 94-7.
91 Letter from the Medical Defence Union to the President of the RCP, dated 8 Dec. 1888. MSS., 2412/140.

92 Annals, 1888, 35: 172.

93 'The statement by Dr Tibbits', RCP, MSS., 2411/128.

94 Swedish mechanical exercise, op. cit., note 78 above, p. 15. 
What Harness hoped to initiate with his impressive capital investments was the largescale capitalization of medicine and the commercialization of medical practices. Predictably, his innovations generated fierce hostility among the professionals who believed their interests and status to be at risk. Perceived as a threat to traditional medical authority, Harness had to be repressed.

\section{Herbert Tibbits and the Gentlemanly Ideal of the RCP}

Herbert Tibbits was a typical ambitious non-élite specialist who carved his own way through the élite dominance of medicine. Riding on the crest of the demand for information on the new technology of medical electricity, his ample publications were all devoted to the description of electrical appliances and technical know-how. ${ }^{95}$ Through these, Tibbits established himself as an authority in technical information. Like other aspiring specialists, in 1878 he founded a hospital, in his case the West End Hospital for Diseases of the Nervous System, of which the Princess of Wales was patroness and the Duke of Buccleugh, President. ${ }^{96}$

Tibbits began his career as a resident medical officer of the Government Hospital in Berbice, Guiana, with his MD degree from St Andrews. He became Licentiate of the RCP in 1865, Member of the RCP Edinburgh in 1874 and Fellow in 1876, and Fellow of the Medical Society of London. ${ }^{97}$ In 1872, the British Medical Journal reported with some surprise, Tibbits was elected as the medical officer for electrical treatment at the Hospital for Sick Children in Great Ormond Street. ${ }^{98}$ However, what enabled Tibbits to advertise his name most impressively in the medical world was his translation in 1871 of $\mathrm{G} B$ Duchenne's L'électrisation localisée, done while he was a medical superintendent of the National Hospital for the Paralysed and Epileptic, Queen Square. By adding notes to each section of his translation, Tibbits capitalized on Duchenne's reputation while establishing his own authority. ${ }^{99}$ Tibbits' translation was welcomed positively in British medical circles. In his long review of medical electricity, Thomas Clifford Allbutt, then a consultant physician to the General Infirmary in Leeds and later Regius Professor of Physic at Cambridge, but also a former student of Duchenne, who had applied electro-

95 Herbert Tibbits, $A$ handbook of medical electricity, London, J \& A Churchill, 1873; idem, How to use a galvanic battery in medicine and surgery: a discourse upon electrotherapeutics delivered before the Hunterian Society upon November 8th, 1876, London, J \& A Churchill, 1877; idem, Improved apparatus and improved methods for applying static electricity (Franklinism) (Abstract of a Lecture at the West End Hospital), London, J \& A Churchill, 1886.

96 According to Rosemary Stevens, during the nineteenth century when specialism tended to be associated with quacks, younger physicians aspiring to be specialists in a particular field used mainly two ways to break the monopoly of the élite circle: the publication of their books and the foundation of their own specialist hospitals. Tibbits seems to have been one of these specialists. See Stevens, op. cit., note 16 above, pp. 27-8.
97 The only available source for Tibbits' career is the Medical directory, London, J \& A Churchill. His name appeared from 1866 to 1895.

98 'Forthcoming report on electrotherapeutics', $\mathbf{B r}$. med. J., 1872, ii: 585.

99 Duchenne was widely known among Victorian intellectuals as a champion of scientifically revived physiognomy. Charles Darwin relied heavily upon Duchenne's theory, set out in The mechanism of human facial expression, for his argument for the evolution of behaviour in The decent of man and The expression of the emotions in man and animals. See Janet Browne, 'Darwin and the face of madness', in W F Bynum, Roy Porter, and Michael Shepherd (eds), The anatomy of madness: essays in the history of psychiatry, London and New York, Tavistock, 1985, vol. 1; see also Sander Gilman, Seeing the insane, New York, J Wiley; Brunner, Mazel, 1982. 


\section{Takahiro Ueyama}

therapy to the treatment of the insane at the Wakefield Asylum, "congratulate[d] Dr Tibbits on his successful labours thus far". ${ }^{100}$ Tibbits was beginning to be regarded as an expert especially in electrical apparatuses and batteries, even designing his own faradic battery, following the example of his master, Duchenne. De Watteville in A practical introduction to medical electricity made a special acknowledgment to Tibbits thanking him for the use of various electrical apparatus. ${ }^{101}$ The Hunterian Society, eager for knowledge of recent electro-therapeutic technology, in 1876 invited Tibbits to give a lecture in which he mainly focused on new electrical devices including "Tibbits' Medical Portable Battery", and various types of electrodes, and how to use them. ${ }^{102}$ Herbert Tibbits, previously an unknown licentiate, thus emerged on the medical scene as an authority on electro-therapeutics.

In July 1892 Harness asked Tibbits to examine and report upon Harness's electropathic belts and other electric appliances. Tibbits consented on the understanding that "[his] fee (100 guineas) should be paid at once and [his] report accepted whether favourable or unfavourable". Six weeks later Tibbits handed over the fully detailed report of "exhaustive experiments". ${ }^{103}$ This report, co-authored for publication with another examiner, Dr Arthur Harries, became the Zander Institute's pamphlet, The treatment of disease by the prolonged application of currents of electricity of low powers. ${ }^{104} \mathrm{Dr}$ Harries, now employed by another electro-therapeutic institute, had previously been the physician to the RCP-paralysed IME.

In his four experiments on electropathic belts, Tibbits observed that a small amount of current was generated through the moist flannel or moist body skin in contact with the discs, and estimated the currents penetrating the skin with Lord Kelvin's galvanometer. In another experiment the belt was placed on the back of a killed and skinned rabbit "so that the muscles, etc., should be good conductors", and the deflection in the galvanometer was recorded. Dr Harries's report was more detailed. He made eight grouped experiments to estimate the currents through flannels saturated with tap water, human perspiration, and a solution of salt and water, and compiled elaborate tables of milliampères obtained in each case. ${ }^{105}$

The RCP's Annals for 1893 clearly indicate the extent to which the College was shaken by the scandal Tibbits caused. ${ }^{106}$ The RCP first became aware of Tibbits' activities when his testimonials appeared in full page advertisements in the Standard and Daily Telegraph. Dr Edward Liveing, the Registrar of the RCP, corresponded frequently with Tibbits, warning him that his "laudatory certificate" on behalf of the Zander Institute flouted the RCP's Resolution and Bye-law enacted in 1882, and requesting him to attend the

100 Thomas Clifford Allbutt, 'Electro-therapy', The British and Foreign Medico-Chirurgical Review, 1871, 48: 38-57.

101 A de Watteville, A practical introduction to medical electricity, London, H K Lewis, 1878, p. vi.

102 Tibbits, How to use a galvanic battery, op. cit., note 95 above.

103 'The statement by Dr Tibbits', RCP, MSS., 2411/128. The Times, 'Tibbits $v$. Morning Newspaper Publishing Company', 6 Feb. 1892.

104 'The treatment of disease by the prolonged application of currents of electricity of low powers, by Herbert Tibbits, MD., etc. together with a report by Arthur Harries, MD., etc. on Mr. Harness' Electropathic Belt and the Electropathic \& Zander Institute', RCP, MSS., 2411/94.

105 See Br. med. J., 1892, ii: 1175-6. Tibbits' report was 9 pages long and Harries's 15 pages.

106 The first reference to Tibbits' case in the Annals appears on 26 Jan. 1893. From that date until the final decision of the RCP on 30 June 1893, Tibbits' case was referred to in more than twenty meetings. All the files on the case are held in the RCP as MSS., 2411/93-139. The first discussion about Tibbits at the Censors' Board took place on 9 Aug. 1892, MSS., 2411/93. 


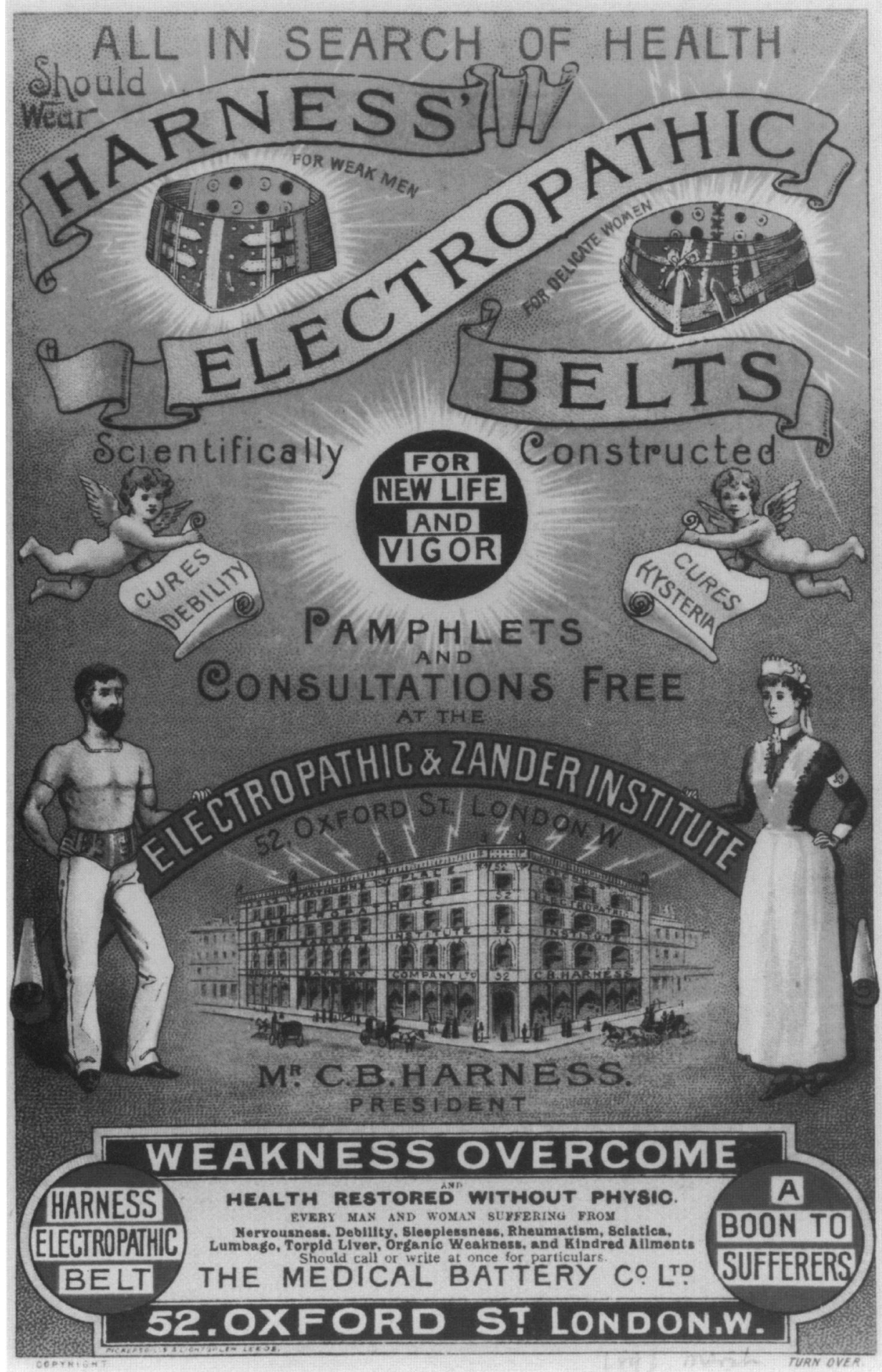

Plate 1: Advertisement for the Electropathic \& Zander Institute. (Reproduced by permission of the Bodleian Library, Oxford, John Johnson Collection, Patent Medicine 10.) 


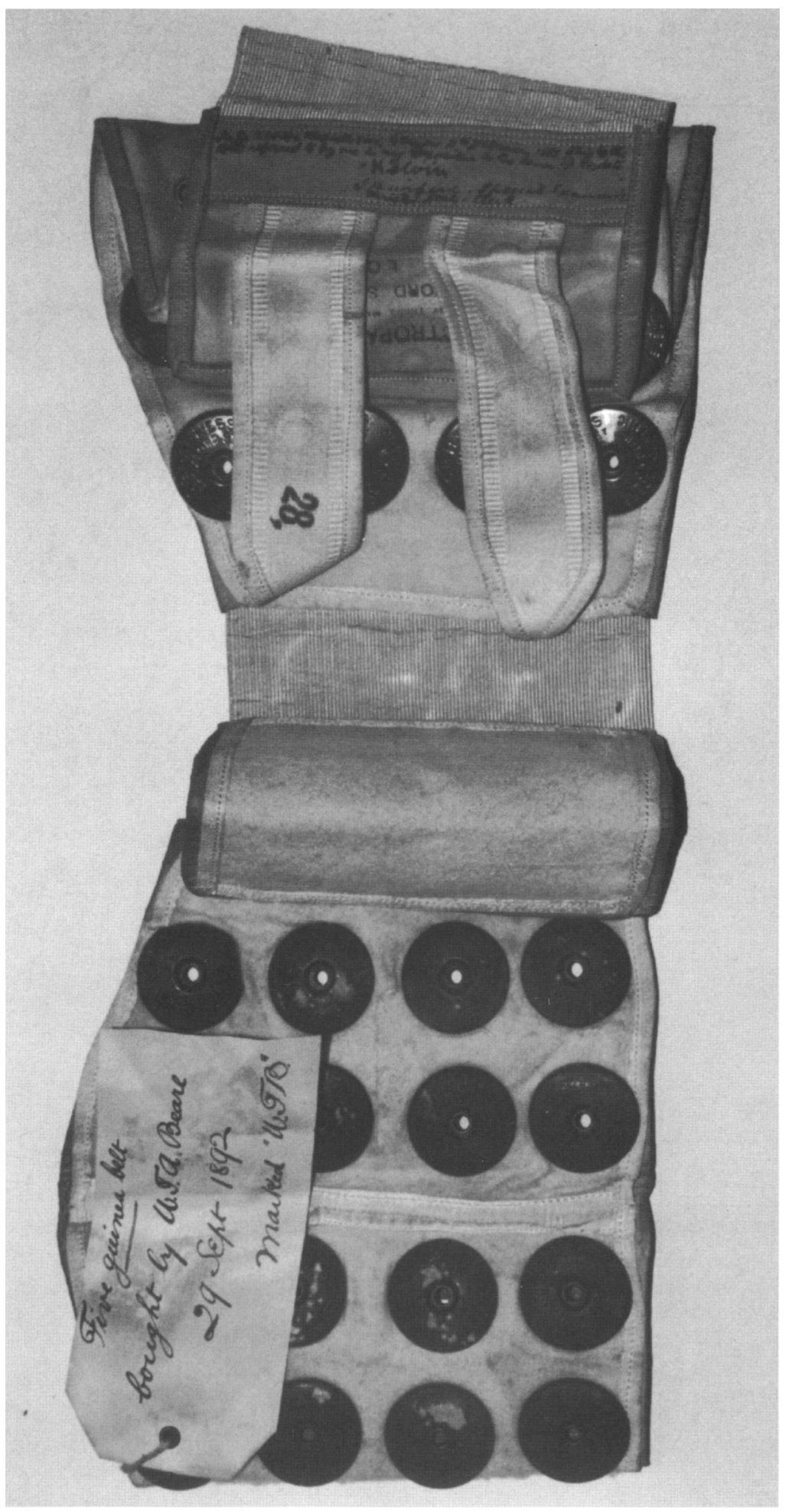

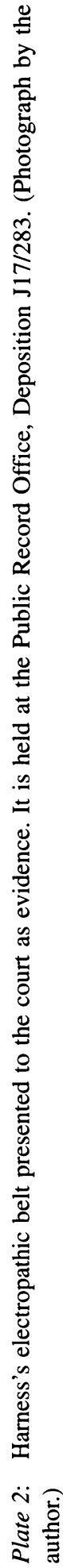


disciplinary meetings of the Censors' Board. This Resolution had been intended to prevent members contributing to medical advertisements. ${ }^{107}$ Tibbits opposed Liveing's denunciation, maintaining that the legal power of the 1882 Bye-law and Resolution was strictly limited to Licentiates. ${ }^{108}$ In his letter to Liveing, Tibbits insisted that

I can not consent to be bound by any Bylaw passed by the College after August 1865 when I obtained my licence. I beg also to observe that the Regulation passed by the College upon July 27, 1882 , was merely an expression of opinion [in] which I was not consulted, and I say also that my Report to Mr. Harness was not "laudatory" in any unworthy sense; nor was it "misleading"! 109

It is significant that at first the RCP censored Tibbits on the grounds not of the 1888 Resolution prohibiting connections with commercial companies but of the 1882 prohibition against "laudatory certificates". Nor did the RCP bring up the matter of professional or gentlemanly ethics at this stage. Writing to Liveing, Henry Roscoe, solicitor for the RCP, admitted that although Tibbits' plea of not being bound by laws enacted after his joining the College could not be sustained, the Resolution might be ruled no stronger than a mere expression of opinion, as Tibbits insisted. As a result, the solicitor and the Censors' Board collaborated to inflate the charge against Tibbits. Finally the solicitor recommended

That though the Licentiate might thus evade the charge in its present form, another might be prepared against him of Unprofessional Conduct under Bye-law CLXXXVIII; and assuming the President and Censors be thereby constitutional judges of what is unprofessional in conduct, they might convict and censure him under that law. [My italics.] ${ }^{110}$

Knowing that Tibbits was notoriously litigious, the RCP seems to have acted with the utmost legal circumspection. He had filed several previous lawsuits for libel, as well as one against the committee of his hospital for wrongful dismissal. ${ }^{111}$ From 27 February 1892 when he lost his post at the West End Hospital and failed to publish his latest book on massage, his reputation came increasingly under attack. The Lancet and the British Medical Journal suddenly turned antagonistic. The Times sniffed at him as a "professional man of straw hired by Harness". After that, the Queen's Bench became a stomping ground for the litigious recidivist.

The RCP's initial aim was not to tackle the problem of the unprofessional conduct of one errant Licentiate. The disciplining of someone guilty of unprofessional conduct was seen as a good legal move, a viable dragnet for rounding up doctors connected with private companies. In any event, as the RCP's solicitor confessed, "what is unprofessional in conduct" was arbitrary in the hands of the College authorities. Neither in the Annals of the RCP nor in its correspondence is there evidence that the President and Censors fully discussed the moral aspects of professional or unprofessional conduct. On the contrary,

107 The Resolution was enacted in 1882 as follows: "that the system of extensively advertising medical works and the custom of giving, whether for publication or not, laudatory certificates is misleading to the public, derogatory to the dignity of the profession and contrary to the traditions and resolution of the Royal College of Physicians". Annals, 27 July 1882, 29: 147-9.

108 See the description of Tibbits' reply in Annals for 27 Feb. 1893, 38: 67-9.
109 Letter from Tibbits to the Registrar, dated 22 Feb. 1893. RCP, MSS., 2411/104.

110 See Annals, 27 Feb. 1893, 38: 68.

111 The lawsuits were filed against Lord R Montagu, Messieurs Macmillan and the Charity Record. See The Times, Tues. 6 Feb., 1893. The statement by Dr. Tibbits to the patrons, patroness and governors, RCP, MSS., 2411/132. Tibbits published the pamphlet to insist on the invalidity of the committee's determination to fire him. 


\section{Takahiro Ueyama}

their censorship was almost exclusively aimed at trapping Tibbits in their legal net. The $\mathrm{RCP}$, in arguing for legal sanctions against violators of professional norms, centred its condemnatory language exclusively on Tibbits" "gross misconduct" and unprofessional or ungentlemanly actions.

The accusation of ungentlemanly behaviour was, therefore, principally a political gesture on the part of élite physicians reacting against the new medical climate created by the rapid establishment of commercial medical institutes like the IME and MBC. That the situation of the MBC was far from anomalous becomes clear when one observes the extent to which late-nineteenth-century capital vigilantly maintained its connections with medical electricity. Its ready-for-use technology offered a promising business opportunity. Even before Tibbits met with the ridicule of élite doctors, commercialized electrotherapeutics was being practised in many quarters.

In June 1887, William Lynd founded the Electro-Dynamic Medical Institute at 21 Bloomsbury Street. He started his business to promote a "scientific administration of electricity" through practical demonstrations in a lecture-room "fully equipped with a number of very costly instruments and apparatus". ${ }^{112}$ Lynd, however, soon used electric current in medical practice. At Bournemouth he attempted to "remove paralysis from the leg of a lad by applying continuous and altering currents in combination". ${ }^{113}$ In September, Dr Dudley Wodsworth followed Lynd's example by opening another electrical room at 6 Oxford Street, Southampton, where " 350 patients have been treated during the last eight months". ${ }^{114}$ Meanwhile, another censored Member of the RCP, Dr Jagielski, preferred to resign his membership of the College, rather than give up his post at an electro-therapeutic institute. ${ }^{115}$

Even Harness, that bullish exploiter of medical authority, found his company a target of exploitation. In July 1887, two former employees of the MBC, named St Clair and Wood, founded the Medical Electric Belt, Truss, and Health Appliance Company Limited, and "started a business in Bond Street exactly similar to that of the [Harness] company" which also sold electric belts and batteries. However, unlike Harness who relied upon doctors' testimonials, St Clair and Wood contrived to establish their authority by affixing the Royal Arms on the premises. But they had neglected to seek the necessary sanction from Her Majesty or any member of the Royal Family, and Harness wasted no time in bringing the case to the attention of the Marlborough Street Police Court. ${ }^{116}$

What was it about these institutes that the RCP found so disturbing? What sort of threat did they present to an organization like the RCP? What did the RCP really want to protect? Both the cases of the IME and the MBC, as well as the controversies which followed, show that as far as medical electricity was concerned, the RCP cared only about safeguarding its own authority, integrity, and tradition, and therefore did what it could to impede the rise of new medical practices partly represented by these companies.

In fact, the MBC, its affiliate the Zander Institute, and the capital that underwrote both organizations provided one of the most perturbing challenges that the RCP had ever

\footnotetext{
112 'Medical electricity', The Telegraphic Journal and Electrical Review, 21 June 1887, 20 : 581.

113 'The medical use of electricity', ibid., 25 Nov. 1887, 21: 544.

114 'Medical electricity', ibid., 16 Sept. 1887 , 21: 544 .
} 
confronted. Because popular electro-therapeutics represented the encroachment of commerce into medical practice, medical electricity was regarded with distaste by the medical authorities. Although the RCP wanted to maintain a monopoly of competence, the commercial power of technology-oriented medical electricity was driving a pecuniary wedge between the medical authorities and general practitioners; in so doing, it was likely to damage the integrity and authority of the RCP.

It was no accident, then, that the main condemnation of Herbert Tibbits by the RCP centred on his refusal to recognize its authority rather than on the content of his testimonials on behalf of the MBC. Whether Tibbits' testimonials were laudatory or not was mainly discussed with antagonistic electricians in court; in its frequently held meetings, the RCP seemed to have no interest in the matter. Tibbits always denied having given a "laudatory" certificate, insisting that his evaluation was neither exaggerated nor dishonest. Responding to his protest, the Censors' Board "decline[d] to admit the Licentiate's interpretation of the word, 'laudatory', which was used in the ordinary sense" [my italics]. ${ }^{117}$ But this questioning of shades of meaning was less important for the RCP than what it termed his "unprofessional conduct": his thoughtless assistance to capital's entry into medical practice and his complicity in the intended demolition of the integrity and authority of the profession. In short, Tibbits was a threat. It is understandable, therefore, that the argument in the meetings of the Censors' Board centred on "whether he acknowledged the authority and jurisdiction of the College". 118

On 7 April 1893 at an extraordinary meeting of the Censors' Board, the first Tibbits attended, the President of the RCP referred first and foremost to this authority. ${ }^{119}$ At the meeting of 15 June: "the discussion mainly turned on the question of procedure, the powers and desires of the College and the Censors' Board respectively under the Bye-Law CLXXXVIII, and whether Dr. Tibbits should be allowed to adorn the College or not". ${ }^{120}$ Furthermore, "The College decided that it would not hear him unless he first acknowledged its authority". ${ }^{121}$ The President and the Censors' Board unsuccessfully spent the entire year "pressing" Tibbits to return to the aegis of the College. But he would be neither persuaded nor intimidated into acquiescence.

Finally on 14 July 1893, the Comitia decided to revoke his licence by sixty-two votes out of the sixty-three. The College appeared to have won. But the very fact that it first spent several months trying to induce one troublesome doctor to change his attitude says much about the sense of authority it was already losing. As Hannah Arendt argues, "authority precludes the use of external means of coercion; where force is used, authority itself has failed. Authority, on the other hand, is incompatible with persuasion, which presupposes equality and works through a process of argumentation".122

117 Annals, 'Extraordinary meeting of the Censor's [sic] Board', 7 April 1893, 38: 78-81. The quotation is on p.81.

118 Annals, 'Extraordinary meeting of the Censor's [sic] Board', 15 June 1893, 38: 121-30. See the letter from Liveing to Tibbits, where Liveing strongly urged him to obey to the authority of the RCP.

119 Annals, 'Extraordinary meeting of the Censor's [sic] Board', 7 April 1893, 38: 80: “[Tibbits] was asked what answer he had to make to the complaint of the Board. He stated in reply that he would not then agree the legal authority of the Board as set forth by the President".

120 Annals, 15 June 1893, 38: 124.

121 Ibid., p. 126.

122 Hannah Arendt, 'What is authority', in Between past and future, New York, Viking, 1961, p. 92. 


\section{Takahiro Ueyama}

More than thirty years, in fact, were needed until such concealed connections materialized enough - or were sufficiently acknowledged - to require legal regulation and an amendment of the Resolution in 1922.

\section{Clashing Medical Electricians}

Electro-therapeutics had been associated with quack medicine since the days of the earliest pioneers of medical electricity. Golding Bird "fulminated against the activities of self-styled medical galvanists", blaming them for "duping and cheating the public". 123 Such an association remained even in the latter part of the century when the technology of medical electricity had reached a relative maturity. While negotiating with the RCP, therefore, the electricians aiming to establish a new field of a managerial medicine began to recognize the dangers of being regarded as shameless charlatans by the medical authorities. Many electricians, particularly members of the Institution of Electrical Engineers, conducted an anti-quack campaign in such magazines as The Telegraphic and Electrical Review. This periodical, published by the Institution of Electrical Engineers, began in 1888 (just after the opening of the IME) a series of pieces denouncing electroquackery. Much work remained to be done by the IME, the author of one column argued, for "charlatans cry aloud for exposure" and "make a determined fight to turn any and every attack to their own advantage". 124

The MBC seemed to these professionals the most flagrant "ubiquitous pest" reaping the profits of extra publicity. ${ }^{125}$ In the 1890 s under its editors Henry Alabaster and Tom Ernest Gatehouse, The Telegraphic and Electrical Review, subsequently renamed The Electrical Review, carried an series of exposés which resulted in the downfall of Harness's electric belt business.

The beginning of The Electrical Review's attack on the MBC was a detailed report of the Jeffery case brought to the Bloomsbury County Court. ${ }^{126}$ On 9 May 1892, Jeffery, a cashier of the Union Bank who feared he was suffering from a sprain, visited the Zander Institute and was introduced by the receiving officer to Simmonds, allegedly an expert in these matters. Simmonds examined Jeffery and recommended that he "wear one of Harness' electric belts with a suspender, in order to obviate what might develop into rupture". Because Jeffery could not afford to pay the belt's full price of $£ 5.5 \mathrm{~s}$. at one go, Simmonds agreed to accept $£ 2$, with an I.O.U. for the $£ 3.5 \mathrm{~s}$. balance. After Jeffrey had worn it for a while, "the belt chafed the skin and caused an eruption, and the illness was so aggravated" that in June he wrote to the company to demand the return of his $£ 2$ and the I.O.U., threatening legal proceedings in default. The MBC offered to exchange the belt on the announced policy of "supply[ing] a good-fitting for an ill-fitting belt free of charge". Eventually, in replying to Jeffery's final letter, the solicitors to the company declared that proceedings had already been taken against Jeffery, who then filed his counterclaim.

\footnotetext{
123 Morus, op. cit., note 36 above, p.49.

124 The Telegraphic Journal and Electrical Review, 17 Aug. 1888, 22: 166.

125 'The medical press and quackery', The
}

Telegraphic Journal and Electrical Review, 24 Aug. 1888, 22: 205.

126 'The Medical Battery Company v. Jeffery', The Electrical Review, 22 July 1892, pp. 99-101. 
At the trial, de Witt, the barrister-at-law for the plaintiff, insisted that Jeffery did not ask to see a medical man, who if required could have been provided on the premises, and that Simmonds was a qualified specialist who had dealt with no less than 16,000 cases of rupture. The counter-examination of Simmonds centred on his qualification for treating hernia. Simmonds responded,

I have studied it all my life; ever since nine years of age.

What was your 'commercial pursuit' before you were employed by the plaintiff?-I was a salesman in the West End of London.

What, in the drapery line?-No, in Oriental furniture.

You do not acquire much knowledge of the treatment of hernia in selling Oriental furniture.-No. ${ }^{127}$

The author of the report in The Electrical Review drew attention to this exchange, concluding, "That is to say, the health, and perhaps the lives of 16,000 people have been wantonly risked, and something like $£ 80,000$ taken as payment". ${ }^{128}$

In court, the electricians launched a full assault on the technique itself. Called to the witness box for the defence as a member of the IEE and an "electrical and consulting engineer of 22 years' standing", T E Gatehouse tested the belt himself and bitterly denied its power to generate any electricity at all. The statement he made when cross-examined by the judge exemplified the reiterated criticism of the electric belts:

Witness: The moisture of the body would be sufficient to set up a current between two dissimilar metals, but you must have a complete circuit. If I place one half of this belt on my stomach, and the other half on my back, I have the elements for a galvanic battery, but there is no completion of the electrical circuit.

His Honour: The witness [Simmonds] says the circuit is completed by the action of the moisture. Witness: That is the internal, and not the external circuit.

His Honour. Why would not a body touched back and front and all around complete a circuit?

Witness: ... I took salt water, and moistened the two parts, and then I connected the copper and zinc with a galvanometer, and so I got a slight deflection of the needle of about 14 degrees. I then put the belt on my legs, and on my arms, and the deflection was not in the slightest degree altered. That shows that when these belts are worn by any patient no electricity passes through the body in any way whatever, but only along the webbing and over the skin surface. ${ }^{129}$

The electricians here conclusively argued that the chemical effect of metals on perspiring skin produced at best only a small amount of electricity, which would never have been of medical use. Putting the electric belt on the skin, they argued, was a nonsensical effort to make the human body into an internal circuit or "a human battery", for the slight amount of electricity generated would have been discharged on the surface of the skin and would not have penetrated the body. In other words, the currents produced by connecting the zinc and copper would be too weak to overcome the resistance of the skin and to pass through the whole body, as medical purposes required.

The Electrical Review's response summarizes the points to which most mainstream electricians adhered. The writer of the column 'Electropathic belts' (probably Gatehouse) reported the result of an experiment made with the assistance of Dr de Watteville, Dr

127 Ibid., p. 100.

128 'Electropathic belts', The Electrical Review, 5 Aug. 1892, pp. 101-2.
129 'The Medical Battery Company v. Jeffery', op. cit., note 126 above, p. 101. 


\section{Takahiro Ueyama}

Inglis Parsons, Dr Lewis Jones, and Henry Lawrence. Its purpose was to estimate the amount of electromotive force necessary to penetrate the body to the therapeutic level: "The E.M.F. required to develop 10 miliampères when the average resistance of the human body is in the circuit, is about 15 volts, so it can readily be seen that the current generated by an electropathic belt is but a mere fraction of 1 miliampère". ${ }^{130}$ This result was applauded by Lawrence in his long lecture, 'The current that cures', serialized from 12 August to 16 September 1892 , as an attempt to save the invaluable practice of medical electricity "from being starved out by the suspicious attitude of [the indifference of the medical profession] or brought into ridicule and contempt by [the blatant absurdities of advertising quacks]". ${ }^{131}$ Lawrence's argument is the same as Gatehouse's:

The people who sell these things tell us, however, that a very small current is sufficient to cure if it be applied constantly, and that their belts excited to action by the perspiration do this, but to pass even a tenth part of one miliampère through such resistance requires 40 volts, and this is at least 10 times more than the best of such belts is capable of. ${ }^{132}$

Lawrence concluded that because of skin resistance, a "ccurrent that cures' is not to be obtained from any body belts or appliances which rely upon the excretion of the skin for their action". ${ }^{133}$ He owed much of his argument to past experts in medical electricity such as W H Stone and W E Steavenson. Steavenson had previously written in relation to the "so extensively advertised" galvanic belts that "No weak current, such as is produced by these battery-belts, could pass through the skin. . . . If the current from these appliances were strong enough to overcome the resistance of the skin, sloughs would, in a short time, be produced at the points of application of the electrodes, a sore first appearing at the point of application of the negative pole". 134

William Stone, a physician at St Thomas's Hospital and Fellow of the RCP, delivered in April 1886 the College's Lumleian Lectures, entitled 'The electrical condition of the human body; man as a conductor and electrolyte'. He there criticized continental electricians like Emil Dubois-Reymond and T A L du Moncel who had failed to consider the effect of the body as polarized and argued that the resistance of the human body itself was "very greatly less than had formerly been supposed"; however he admitted that the skin, acting as a insulator, increased estimated resistance.

In order to reduce contact-resistance by the skin possibly to zero and to obtain an absolute measurement, Stone attempted to contact poles of electricity with a large area of the skin. To do so, he wrapped "a flexible strip of lead around the hands or feet, previously soaked in brine". ${ }^{135}$ In the experiments, he charged a healthy adult for ten minutes, then discharged through the galvanometer to estimate the currents from the body. The galvanometer recorded "the great initial throw" to a high level of current, then came down

\footnotetext{
130 'Electropathic belts', op. cit., note 128 above, p. 101 .

131 'The current that cures', The Electrical Review, 1892, 12 Aug. pp. 208-9, 19 Aug. p. 239, 26 Aug. pp. 262-3, 2 Sept. pp. 282-3, 9 Sept. pp. 330-1, 16 Sept. pp. $350-1$.

132 Ibid., pp. 262-3.

133 Ibid., p. 263.

134 W E Steavenson, 'The therapeutical
}

\author{
applications of electricity' read in the section of \\ pharmacology and therapeutics at the fifty-second \\ annual meeting of the British Medical Association, \\ Br. med. J., 1884, ii: 1008-11. \\ 135 W H Stone, 'Abstracts of the Lumleian \\ Lectures on the electrical condition of the human \\ body; man as a conductor and electrolyte', Br. med. \\ J., 1886, i: 728-30, 812-13, 863-5, p. 813.
}




\section{The Electro-Therapeutic Institutes and the RCP}

again but not to the line of zero. This showed that the human body was capable of generating high electromotive force by self-induction. For electrotherapeutic purposes, Stone thus argued, electricity was useful; however, the resistance of the human body varied with the types of disease.

On 23 September 1892, The Electrical Review, allegedly taking up the cudgels on behalf of the public, launched another militant attack on the activities of the MBC: "[T]o take advantage of that helplessness to wring money from the sufferer stamps the man [Tibbits] as a being beneath contempt; yet of such a class are the men who fatten by the sale of useless electrical appliances, and who should be effaced by the strong arm of the law". Tibbits was pilloried as an educated man who only too easily wrote testimonials for the benefit of charlatans. The author suggested that though "Dr. Tibbits is, we believe, supposed to be a recognized authority in the medical world", in fact he took responsibility only "to gild the counterfeit and make it appear to be all of sterling gold". ${ }^{136}$ In the article, the main conclusions of Tibbits' pamphlet, The treatment of disease by the prolonged application of currents of electricity of low powers, were quoted to demonstrate Tibbits' "most incredible ignorance of electrical laws, an ignorance which utterly unfits him to speak as an authority". Scarcely two weeks later, on 6 October, Tibbits sued the proprietors of the magazine, Henry Alabaster, Tom Gatehouse, and Harry Robert Kemp, claiming $£ 5,000$ for libel and the damage he had suffered. ${ }^{137}$ The subsequent court argument attracted much attention from the medical profession, and the Lancet and the British Medical Journal issued prompt, detailed reports on 'Tibbits $v$. Alabaster and others'. ${ }^{138}$

At the Queen's Bench, "having made a lengthy opening, giving a history of his professional antecedents", Tibbits animadverted upon the conduct of the defendants in staining his reputation. ${ }^{139}$ However, Tibbits' lawsuit was in fact financed by Harness, who was therefore the real plaintiff, because Tibbits was "an undischarged bankrupt" at the time of action. ${ }^{140}$ The principal witness for the plaintiff was Tibbits himself, while the principal witnesses for the defence were numerous electrical engineers and scientists, including, most eminently, Lord Kelvin, President of the Royal Society. In court, Lord Kelvin examined one of Harness's belts and testified that in the condition in which it was sold, the connection of the metal discs was imperfect, so that it would never be capable of generating electricity at all, though "in cross-examination, he stated that putting the belt on the body with metallic connections there would be a small current". ${ }^{141}$ Professor

\footnotetext{
136 'Electricity and the medical profession', The Electrical Review, 23 Sept., 1892.

137 The Records of Tibbits' trials are held in the Public Record Office: Depositions: J17/283, IND 1/1675; Pleadings: J54/765, Jan.-Mar.,1893; Affidavits: J4/4891. See especially the writ issued on 6 Oct. 1892 and submitted to the High Court, 'Statement of Claims' by Tibbits, XC 5658, J54/765. The Depositions of J17/283 hold the pamphlet of the Zander Institute; the Harness Electropathic Belt was itself presented as evidence to the court. This belt has a tag with Lord Kelvin's memorandum in his own writing. (See Plate 2.)

138 'Medico-legal and medico-ethical, Queen's
}

Bench division before Mr Justice Mathews and a special jury, Tibbits $v$. Alabaster and Others', Br. med. J., 1893, i: 436; 'Tibbits $v$. Alabaster and others', Br. med. J., 1893, i: 368, 436; 'Tibbits $v$. Alabaster and others', Lancet, 1893, i: 425, 439-40, 447, 487; 'Dr Tibbits and the Medical Battery Company', Br. med. J., 1893, ii: 1182.

139 The courtroom battle between Tibbits and The Electrical Review attracted much public attention. See The Times, 16, 17, 18 Feb. 1893.

140 The Times, 6 Feb. 1893.

141 'Medico-Legal and Medico-Ethical', Br. med. J., 1893, i: 436. 


\section{Takahiro Ueyama}

Silvanus Thompson, another witness who had himself worn the belt, made a sarcastic remark concerning the therapeutic effect which the low dosage of electricity thus generated could produce. ${ }^{142}$ Tibbits replied, "scientific men always differ (laughter)". ${ }^{143}$

The verdict was returned for the defendants on 17 February 1893. Nevertheless, the legal battles between Tibbits and journalists did not end here. The day after the verdict, the Morning scorned Tibbits as "a professional man of straw" and wrote: "the jury, by giving a verdict for the defendant, have found that the plaintiff had virtually no reputation to maintain". ${ }^{144}$ Another newspaper, Science Siftings, entered the arena on 4 March crowing over "a distinct triumph of right over wrong in its most drastic sense, so far as Dr Tibbits is concerned, in having endeavoured to give impetus to the imposition upon the suffering public of a worthless appliance". ${ }^{145}$ Tibbits at once sued both newspapers; in both cases, his claims were rejected.

This was the downfall of the litigation maniac. His licence was revoked by the Royal College of Physicians, his name was struck off the Medical register in 1895 by the General Medical Council, and he was branded as "a creature" and a commercial quack in the press. ${ }^{146}$ Yet, though the electrical engineers won the battle with the MBC, this triumph, as we have seen, did not lend itself to their original purpose of obtaining the support of élite doctors in the RCP. The Royal College of Physicians adhered to its legal regulation. Amendment was postponed until 1922.

\section{The Amendment of the Resolution}

After the battle with the IME, the equanimity of the RCP was broken: the spectre of a commercialized profession continued to make its appearance from time to time. ${ }^{147}$ When the Bye-law and Resolution in question were amended in 1922 to allow its members' official affiliation with companies and institutions supplying medical services for financial

142 'Tibbits $v$. Alabaster and Others', Lancet, 1893, i: 439-40. Thompson "proved that a current greater than that which the belt generated could be produced by merely plunging a pin and a needle together into a small drop of ink. With a moist skin he had obtained a current equal to one-fifth of a milliampère, with a dry skin a current as small as the two-hundredth part of that quantity".

143 The Times, 6 Feb. 1893.

144 'Harness' Belt', Morning, 18 Feb. 1893.

'Tibbits $v$. the Morning Newspaper Publishing Company, Limited', Br. med. J., 1894, i: 332.

145 'Harness' belt, the verdict of a British jury', Science Siftings, 4 March 1893, RCP, MSS., 2411/113. Tibbits sued the proprietors of the newspaper, claiming $£ 1,000$ in damages, and published the statement of claim as Tibbits $v$. Messrs. Woolf \& Hymann, on 21 April, 1893. The pamphlet is held in the RCP, MSS., 2411/113.

146 Tibbits was summoned by the General Medical Council on 18 Nov. 1893 and eliminated from the Register. See Russell Gordon Smith, 'The professional conduct jurisdiction of the General
Medical Council: its compliance with aspects of substantive and procedural justice', $\mathrm{PhD}$ thesis, University of London, 1990, Appendix III, p. 896. See also his Medical discipline: the professional conduct jurisdiction of the General Medical Council, 1858-1990, Oxford, Clarendon Press, 1994.

147 In the Annals from 1893 to 1922 there are many cases of Fellows, Members and Licentiates being summoned by the Censors' Board in connection with their relationships with commercial companies and institutions. For example, in the meeting of 5 June 1894, a Fellow was censored for his partnership with a company in Brighton, and a Licentiate (see the Annals, 38: 247), for being consultant to a Nursing Home (38: 248). On 9 April 1897, Dr Robert Farquharson was summoned for his connection with Bovril Company Ltd., which traded in dietary articles (40: 95). The most typical case was that of Dr M E A Wallis who was associated with the Sandow Curative Institute but was removed from its Registry after being censored by the General Medical Council. For the last case, see RCP, MSS., 2412/285 and the Annals, 54: 47-9. 


\section{The Electro-Therapeutic Institutes and the RCP}

gain, the uproar caused by the IME was recalled as the turning-point which had made this change possible.

In 1920 the move of a Fellow of the RCP, Dr Edmund Spriggs, to Ruthin Castle, Limited, in Wales, manifestly "an institution treating diseases for profit", initiated a debate among the Censors which moved them to reconsider the legal regulation of the RCP. Dr Spriggs, who had been an eminent consultant at Guy's and St Thomas's hospitals until he fell ill, was summoned to the Censors' Board to defend himself. He argued that effective diagnosis and treatment required a large-scale organization with a strong financial base and the co-ordinated teamwork of specialists. In doing so he invoked the IME's earlier attempt as a prototype, though primitive, of a useful alliance between the medical profession and capital, although he admitted that it was "a far cry from the electrical emporium of Regent Street to a modern private hospital or sanatorium". ${ }^{148}$

On 26 January 1922, Sir Humphry Rolleston, the Senior Censor of the RCP, proposed to the Comitia "That the Censors' Board should look into the question of how the Resolution of 25th Oct., 1888 should be interpreted in view of recent developments in medical practice". ${ }^{149}$ Rolleston argued "that owing to the increasing complexity of medicine and the growth of specialities, it was becoming common for medical men to unite together for the purpose of attaining better diagnosis or better treatment than could be secured by an individual physician". Hence "group medicine", "diagnostic clinics" or "institutional treatment" (by which Rolleston meant the "teamwork" of many clinicians and technicians with different specialities in an institution) was required to meet the demands from society and patients. ${ }^{150}$ Such specialized auxiliary examinations were expensive, but the association with public companies would enable patients to get "a pecuniary advantage from the closer union of special investigation, whether in the form of a 'group', 'team' or 'firm' or as brought together in an institution". 151

The members of the Comitia agreed and the President, Sir Norman Moore, nominated the Censors' Board, headed by Rolleston, to investigate this enquiry. On 28 April, a report recommending the alteration of the Resolution was submitted to the President. Pointing out the public's need for specialized care and examination as well as its reliance on corporate medical institutions providing such services, the report emphasized the responsibility of the College to promote a medical service oriented towards the welfare of society:

The welfare of the community must transcend the traditions of any of its component units. This College is but a unit of the body-politic, though a unit of high valency. They feel, therefore, that, if with the passage of years it has come about that conflict exists between the ordinances of the College and what they conceive to be the highest interest of the community, no course is open to them but to advise their amendment. ${ }^{152}$

\footnotetext{
148 'Dr Spriggs' speech planned (but not delivered) for the meeting of the RCP, 19 Oct. 1922', RCP, MSS., 835/47, pp. 1-8, see p. 2.

149 'Report from the Censors' Board dated April 28th, 1922, recommending the alteration of the College (dated October 25th, 1888), and of Bye-law CLXXVIII', RCP, MSS., 835/50.

150 Annals, 'College meeting', 26 Jan. 1922, 51 :

71. The various meetings in relation to these
}

alterations were held between $26 \mathrm{Jan}$. and 19 Oct. 1922; 8 May , 51: 77; 11 May, 51: 108-13; 7 July 51: 119; 13 July, 51: 125-34; 20 July, 51: 132-4, 19 Oct., 51: 156-63.

151 Annals, 'College meeting', 11 May 1922, 51: 108.

152 'Report from the Censors' Board dated April 28th, 1922', op. cit., note 149 above. 
In the inter-war years, the ethos of public service and public duty, which electrical engineers had used in establishing the IME and which élite physicians had rejected in favour of the gentlemanly ideal, was now taken up by the medical profession.

In subsequent meetings of the Comitia, the amendment of the Resolution and the Byelaw was furiously discussed. Diehards such as Sir John Bradford and Sir Wilmot Herringham resisted any alteration of the rules, fearing the effect of commerce on the profession once "group medicine" was allowed. Some radicals, represented by William Dowson and Dr James Taylor, tried to abolish regulations altogether. Finally, on 19 October 1922, both the Resolution and the Bye-law were amended. The new Resolution officially allowed Fellows and Members to be financially associated with medical institutes; the Bye-law was scarcely altered, since it was not considered a serious obstacle to "group medicine". Debates originating in the 1880 s were eventually resolved in the legal forms of 1922 .

\section{Conclusion}

Through an analysis of the uproar caused by the IME and the MBC, I have investigated several aspects of the clashes between professionals, capitalists, and promoters of technology which created a new social environment for the development of medicine. In doing so, I have attempted to show that, in an embryonic form, managerial medicine began in the late nineteenth century. The establishment of corporate-style electrotherapeutic institutes as early as 1888 , kept at arm's length by the Resolution the RCP enacted that year, was a manifestation of the commercialism, specialism, and public service ideal which challenged the medical ethos of gentlemanly professionalism. This new development may have been impeded by forceful RCP resistance, but it was eventually accepted as a reality by the RCP's legal proceedings in the 1920 s.

Well before the turn of the century, new skills and technologies were already influencing medical practice. As medicine became increasingly specialized in the late nineteenth century, medical authority began to pass from the expert coping singlehandedly with all the essentials of diagnosis and treatment to institutions and group medicine based upon the combined activities of many interdependent workers.

Medical electricity was a good example of treatment which relied on technology. It required investment in costly apparatus and facilities, as well as a number of technical workers to operate the machines, and by the late nineteenth century, it had become a relatively mature technique. It therefore provided a convenient niche for fin de siècle capitalists seeking marketable technologies and practices. Unlike mid-Victorian medical entrepreneurship, the alliance of capital and medicine represented by the IME and MBC made every effort to combine medicine and technology in new, profitable enterprises.

In the three-sided battle described in this paper, the RCP, despite its regulatory power, was put on the defensive when faced with the challenge of a rival profession's competing ideals and its open capitalization of medical activities. In the $1880 \mathrm{~s}$, however, many doctors were quietly engaged in profitable activities; whatever the College said to the contrary, its official morality of gentlemanly professionalism was already in jeopardy. Maintaining, at least on the surface, its own authority and integrity was all the RCP could do in the face of the determination of companies to penetrate medicine. 
Thus, at least with respect to late-nineteenth-century England, the historiography of medicine and technology requires us to consider an additional factor: the commercial strategies used by entrepreneurs mimicking professional activities and by medical men and professional electricians united by their relationship to the cash nexus. In the most industrially and commercially developed country of the time, medical electricity was accepted as a practical therapeutic method not merely because of its theoretical advances but also because it adopted new technical knowledge and apparatus, which together gave rise to the beginnings of collaboration between technology and capital. 